"This is the peer reviewed version of the following article: [international journal of auditing, 2018], which has been published in final form at [https://onlinelibrary.wiley.com/doi/abs/10.1111/ijau.12116]. This article may be used for non-commercial purposes in accordance with Wiley Terms and Conditions for Self-Archiving." 


\title{
Interim reviews and the association between partner rotation and audit fees
}

\begin{abstract}
This paper considers whether the association between partner rotation and audit fees varies based on if the partner is rotated before the interim review or annual report audit. Consistent with prior literature (Stewart et al., 2016; Sharma et al., 2017; Ferguson et al., 2017) there is some evidence of higher fees in the year of rotation, but we find this effect is driven by partner rotations that occur before the interim review which are 7.14 percent higher on average. We argue that rotations before the annual report audit are less likely to be planned, and thus audit firms cannot pass on increased costs due to a weaker bargaining position. Supporting evidence is provided as results only persist when client bargaining power is low, and in contrast there are lower fees for rotations that occur before the annual report audit when client bargaining power is high.
\end{abstract}

Keywords: audit fees; partner rotation; auditor reviews; interim reports; interim reviews; bargaining power; audit delay

JEL Classifications: G38, M42, M48 


\section{INTRODUCTION}

Regulators have expressed concerns around auditors' over-familiarity with clients, leading to calls for auditor rotation; however, there has also been apprehension that auditor rotations may impose costs (e.g., Australian Securities and Investments Commission (ASIC), 2007; Public Company Accounting Oversight Board (PCAOB), 2011; Treasury of Australia, 2012; Crowe Horwath, 2012). Prior literature has found that audit partner rotations can result in higher audit quality (e.g., Fargher et al., 2008; Lennox et al., 2014; Laurion et al. 2017), although there is evidence to the contrary (e.g., Litt et al., 2014). Partner rotations are costly and have been found to lead to higher audit fees, which vary based on client size segments (Stewart et al., 2016; Sharma et al., 2017; Ferguson et al., 2017). However it is not clear whether the higher audit fees surrounding partner rotations are caused by greater audit effort, a fee premium, or the audit partner convincing the client to purchase more assurance. Documenting both the costs and benefits of partner rotation is important as it allows regulators to make an informed assessment of partner rotations. We extend this literature by disaggregating partner rotations into whether the rotation occurred before the half-yearly financial statement (hereafter described as an interim review) or before the annual report audit. We argue that differences in when the partner is rotated reflect relative client-auditor bargaining power and thus the ability to pass on the cost of rotation.

Companies listed on the Australian Stock Exchange (ASX) must disclose both halfyearly (interim) financial statements and an annual report. The interim financial statements must be reviewed by an auditor, as opposed to having a full audit conducted. ${ }^{1}$ Thus a new lead audit partner could first sign-off on an assurance engagement at the interim review or the annual audit. We argue that partner rotations occurring earlier in the year before the interim review are more likely to represent planned rotations, in which the new audit partner can

\footnotetext{
${ }^{1}$ A review provides a lower level of assurance relative to an audit. The differences in assurance standards between an audit and a review are discussed in more detail in the Institutional Setting section.
} 
learn about the firm in a lower risk assurance engagement. Alternatively, partner rotations occurring later in the year before the annual audit are less likely 'planned' but rather stem from client dissatisfaction with the partner, or the audit firm managing unexpected changes in workloads. This would suggest the audit firm has less bargaining power and cannot charge a fee premium or pass on the costs of audit partner rotation when the partner is rotated before the annual report audit. We use the Australian setting as interim financial statements are required to be reviewed and disclosed with the audit partner's name identified. This contrasts with other jurisdictions such as the United States (U.S.), where interim financial statements must be reviewed, but the disclosure of the review report with the interim financial statements is voluntary, and disclosure of audit partner identities has only recently been mandated. Thus, Australia provides a strong institutional setting to examine the role of partner rotation timing on the functioning of the audit market.

Our sample is based on the largest 500 Australian publicly listed companies on the ASX in any year through the period 2007 - 2014. As we require companies to have data over the whole period and exclude financial institutions, our final sample is 3,480 firm-year observations from 566 unique firms. We document a rate of 22 percent (769) partner rotations, similar to Stewart et al. (2016). Eighty-five percent of partner rotations occur before the interim review suggesting rotations are often planned, while unplanned rotations before the annual report audit are a sizable minority. We find that audit fees are significantly higher by 7.14 percent in the year of a partner rotation only when the rotation occurs before the interim review. Additionally, audit fees are significantly lower by 12.63 percent for rotations occurring before the annual report audit for clients with higher bargaining power. This result is robust to controlling for partner rotations due to regulatory requirements for periodic rotation. 
Overall, we interpret our results as suggesting that higher fees around audit partner rotations vary based on relative auditor-client bargaining power. We argue that rotations before the interim review are more likely to be planned, providing the audit firm a stronger bargaining position to pass on the cost of rotation and any additional assurance work to clients through higher audit fees. Consistent with this interpretation, the results differ based on client bargaining power, with higher (lower) power segments linked to lower (higher) fees for rotations occurring before the annual report (interim review) audit. Furthermore, we find significant increases in the reporting lag for both rotations at the engagement immediately following the rotation (i.e., at the interim review or the annual report audit) despite audit fees being 11.96 percent higher on average in rotations occurring before the interim review relative to the rotations before the annual audit. This suggests that the difference in audit fee is not driven by the cost of greater auditor effort; but rather the pricing effect reflects relative client-auditor bargaining power. Thus our main contributions are to highlight that the costs of partner rotation are not always immediately passed on to clients, and documenting that relative bargaining power influences the ability of the auditor to recoup the costs of rotation. One interpretation of our results is that planned rotations appear to maintain client satisfaction allowing the auditor to recoup the costs of rotation while poorly managed rotations result in further costs to the auditor from discounting fees for more economically important clients.

This paper contributes to the literature on the assurance of interim financial statements by examining how audit firms manage client and partner relationships across interim and annual reports to provide new insight into audit market structure. Current research on interim assurance has predominately taken the perspective of clients investing in greater assurance levels (Ettredge et al., 1994, 2000; Krishnan \& Zhang, 2005; Haw et al., 2008; Bédard \& Courteau, 2015). We find that the interim review lag is significantly shorter than the annual 
audit lag by almost 13 days, which is consistent with auditing standards requiring significantly less assurance on an interim review.

The reminder of the paper is structured as follows. Section 2 provides background information on the institutional setting, reviews the previous literature, and develops the hypotheses. Section 3 describes the research method and sample. Section 4 reports the results, and Section 5 concludes.

\section{LITERATURE REVIEW AND HYPOTHESIS DEVELOPMENT}

\section{Institutional Setting}

Companies listed on the ASX must disclose half-yearly and annual financial statements as material price-sensitive announcements. The half-yearly financial statements are mandated periodic disclosures that report on the first six months of the financial year. Half-yearly reports are governed by AASB 134 Interim Financial Reporting, which requires the preparation of condensed financial statements. Quarterly financial statements are not mandated in Australia. ${ }^{2}$

The disclosure of the half-yearly financial statements must also include the interim review report. ${ }^{3}$ Reviews offer a lower level of assurance than an audit. The Australian Securities and Investments Commission (ASIC) describes an audit opinion as expressing whether the financial statements are prepared in accordance with the financial reporting framework and are free from material misstatement. In contrast, a review expresses whether anything has come to the auditors' attention that signals the financial statements are not prepared in accordance with the financial reporting framework. ${ }^{4}$ Krishnan and Zhang (2005)

\footnotetext{
${ }^{2}$ An exception is for mining, oil and gas exploration entities, which have to disclose a quarterly cash flow statement. The quarterly cash flow statement does not have any assurance requirement. The ASX has the discretion to waive this requirement.

${ }^{3}$ Firms have the option of having the interim statements audited or reviewed, although only a negligible amount choose for them to be audited (Chen et al., 2007).

${ }^{4}$ http://www.asic.gov.au/asic/ASIC.NSF/byHeadline/For\%20users\%20of\%20financial\%20reports\#9
} 
summarise the differences between a review and an audit as providing negative and positive assurance on misstatements, respectively.

The Australian Auditing and Assurance Standards Board has different standards on reviews for assurance practitioners who are (ASRE 2410 Review of a Financial Report Performed by the Independent Auditor of the Entity) and who are not (ASRE 2400 Review of a Financial Report Performed by an Assurance Practitioner Who is Not the Auditor of the Entity) the auditor of the entity. The underlying rationale is that an assurance practitioner performing a review, who is not the auditor, may be less knowledgeable about the entity and should perform more tests to reach the same level of limited assurance. ASRE 2400 suggests, but does not require, that more procedures are performed by the assurance practitioner to obtain understanding, such as reading documentation and considering significant risk (e.g., material weakness in internal control). However, we do not know how much time a review takes relative to an audit, and this is further complicated as audit planning and testing of internal controls would likely have benefits for both engagements.

The Corporate Law Economic Reform Program (Audit Reform and Corporate Disclosure) Act of 2004 (Commonwealth of Australia, 2004) requires the mandatory rotation of audit partners every five years. Individuals cannot be the audit or review partner in the audit of a listed entity for more than five successive years, or for more than five out of seven successive years. As regulators in Australia require partner sign-off data on both interim reviews and annual audits, unlike in the U.S. or Canada, Australia is a strong institutional setting to examine the effect of audit partner rotation timing.

\section{Literature Review}

Prior literature has studied both the benefits and costs of audit partner tenure, and audit partner rotation. In an Australian setting, Carey and Simnett (2006) find a negative 
association between audit partner tenure greater than seven years and going concern opinion propensity, but no relationship with discretionary accruals. Fargher et al. (2008) find lower (higher) discretionary accruals in the initial years of a partner from the same (new) audit firm. They argue that partner rotation within the same audit firm has the benefits of both 'fresh eyes' in increasing objectivity and retaining institutional knowledge of the client. Taiwanese evidence shows that discretionary accruals decrease with audit partner tenure (Chen et al., 2008). However, any effect may be driven by particularly high familiarity between the auditor and client (Chi \& Huang, 2005). ${ }^{5}$ European evidence also contrasts with Australian findings, as there is no evidence of an association between audit partner tenure and going concern propensity in Spain (Ruiz-Barbadillo et al., 2009) or Belgium (Knechel \& Vanstraelen, 2007).

More direct evidence on partner rotation and audit quality finds that mandatory partner rotation is associated with less audit adjustments in China (Lennox et al. 2014). In contrast using U.S. data, Litt et al. (2014) find that partner rotation is associated with lower financial reporting quality, in terms of using discretionary accruals to meet-or-beat analyst forecasts and going concern propensity. However, recent evidence from Laurion et al. (2017) finds that following a rotation there is a greater likelihood of restatement discoveries, increases in deferred tax asset valuation allowances and decreases in positive special items, but no evidence of reduced restatements or increased write-downs.

ASIC (2007) identified that audit partner rotation could lead to an increase in costs for both the audit firm and client. Academic research has subsequently examined the association between audit fees and partner rotation. Based on semi-structured interviews with U.S. audit firm partners, Dodgson et al. (2017) find that a rotation needs to be planned well in advance to reduce audit risk and to maintain relationships with the client's audit committee and

\footnotetext{
${ }^{5}$ Chi et al. (2009) provide supporting evidence by showing that the introduction of mandatory rotation may increase discretionary accruals.
} 
management. Audit firms may assign more resources to important clients in order to manage a rotation. These additional resources are dedicated to the client with the expected economic benefit being a greater likelihood of client retention, but may also increase costs.

Using Australian data over 2007 to 2010, Stewart et al. (2016) find higher audit fees for partner switches in Australia. They argue that higher fees around partner rotations could be due to a loss of client-specific knowledge increasing costs, or the incoming audit partner convincing the client to purchase more assurance. ${ }^{6}$ Voluntary rotation may occur due to audit firm constraints around planning, and can also arise from client dissatisfaction with their audit partner. Stewart et al. (2016) argue that audit firms are less likely to be able to pass on increased costs when rotations arise from client dissatisfaction. Overall, they find that both mandatory and voluntary rotations are associated with higher audit fees, with only voluntary rotations associated with higher fees in the years following the rotation. They also document that there is no association between higher audit fees for partner rotation in mid-size clients, which they argue is due to greater competition in that market segment. Ferguson et al. (2017) also find a greater increase in audit fees for mandatory partner rotations in Australia, and emphasise that the supply-side costs for partner rotation would be greater for smaller audit firms. Using U.S. data, Sharma et al. (2017) document higher audit fees after partner rotations, and that the effect is stronger for clients of non-Big 4 auditors.

\section{Hypothesis Development}

Partner rotations can be a costly and disruptive event in audit engagements (Stewart et al., 2016; Laurion et al. 2017; Sharma et al., 2017; Ferguson et al., 2017). Partner continuity on engagements provides the opportunity to develop a strong working relationship with the

\footnotetext{
${ }^{6}$ Existing audit engagements may have lower audit fees due to the incumbent audit partner agreeing with the client to waive certain fees and write off some costs of the engagement. The new partner may be less willing, or be under pressure to not accept existing write-offs, resulting in a higher audit fee. This is consistent with Taylor (2011) documenting that audit partners charge different fees.
} 
client and reduce audit costs through operational familiarity (Chen et al., 2009; Treasury of Australia, 2012). Rotating partners results in the loss of knowledge about the client leading to a potential reduction in audit quality (Litt et al., 2014; Ferguson et al., 2017). Auditorinitiated rotations may create issues in the auditor-client relationship if the client's preferred partner is being replaced with an incoming partner that lacks familiarity with the client and provides poorer outcomes such as a longer audit delay (Houghton et al., 2013; Sharma et al., 2017; Dodgson et al., 2017). Alternatively, client-initiated rotations may stem from issues with the incumbent partner and their ability to achieve the desired outcomes at a reasonable level of quality and timeliness. ${ }^{7}$ Thus, rotations may reflect greater levels of dissatisfaction in the client, and are commonly cited as being a 'tipping point' for clients putting the audit out to tender (Treasury of Australia, 2012; Houghton et al., 2013).

However, these issues can be mitigated with sufficient planning, where arrangements are made to train and familiarise the incoming auditor with the client and their operations to preserve audit quality, reduce audit costs, and maintain auditor-client relationships prior to the rotation (Lennox et al., 2014; Dodgson et al., 2017). We argue that rotations before the interim review would likely represent a more planned rotation that are mutually beneficial for the client and partner. Clients would prefer that the new partners' initial engagement is the interim review as the partner could gain client knowledge in a setting where there is a lower reputational risk. ${ }^{8}$ Equally, if the partner is rotated before the interim review, it may enable audit firms to plan their work load for the year and maximise economies of scale to cover fixed costs (Higgins et al., 2016). The interim review would provide more opportunity for the new partner to convince the client to purchase more assurance (e.g., at both the interim and annual audit) to respond to financial reporting and audit issues they identify at the interim

\footnotetext{
${ }^{7}$ Clients are less likely to experience these issues with their partner of choice, but mandatory partner rotation requirements result in clients being audited by another partner not of their choosing.

${ }^{8}$ Consistent with a steep learning curve on a new audit, Cassell et al. (2016) find that audit quality is lower when the audit engagement occurs later in the year although their focus is on initial audit firm engagements.
} 
review to lower the level of audit risk (Dodgson et al., 2017). In contrast, rotations before the annual report audit may be more likely to represent unplanned rotations which may occur due to unforeseen circumstances (e.g., failing partner health between the interim and annual audit), client dissatisfaction with their previous partner, or audit firms managing partner workloads. ${ }^{9}$ Different partners for the interim review and annual report audit may also require more audit effort by each auditor, consistent with ASRE 2400. As the interim review provides a useful training ground for the partner prior to the more important annual report audit, rotations occurring at the annual report audit are more likely to experience the dysfunctional effects of rotation, namely lower audit quality from the steeper learning curve (Cassell et al., 2017; Pacheco-Paredes et al., 2017). The potential combination of client dissatisfaction, lower audit quality and/or increased costs may create a shift in the relative bargaining power from the auditor to the client, where clients have less economic incentive to remain with the auditor and thus have an opportunity to negotiate more favourable terms with the auditor. The reduction in audit quality is likely to be exacerbated for engagements of larger clients, granting them greater bargaining power particularly when they are more economically important to the client (Houghton et al., 2013). Thus, when the partner is rotated before the interim review, audit firms may have a stronger bargaining position relative to rotations before the annual report audit. ${ }^{10}$

We predict that planned partner rotations before the interim review would result in higher audit fees as audit firms can either pass on the costs of partner rotation or convince the client to purchase more assurance. In contrast, partner rotations before the annual report audit would represent an unplanned rotation and thus audit firms would be less able to pass on the

\footnotetext{
${ }^{9}$ These unplanned rotations due to unforeseen circumstances and client dissatisfaction are likely to occur later at the annual audit given the need to find a suitable replacement partner at short notice.

${ }^{10}$ Prior literature has found that a stronger bargaining position is associated with higher audit fees for initial audit engagements (Casterella et al., 2004; Shailer et al., 2004).
} 
costs of partner rotation or identify areas of risk that require more assurance. This leads to our hypothesis, stated as:

H1: Audit fees are positively associated with partner rotations that occur before the interim review.

As discussed above, significantly higher audit fees around partner rotations could be explained by differences in audit effort or relative client-auditor bargain power. Thus, we provide additional insight by considering the audit lag (the number of days from the end of the financial year to the audit report date). Prior literature has argued that the audit lag can proxy for audit effort and efficiency (Ashton et al., 1987, 1989; Bamber et al., 1993; Knechel \& Payne, 2001). Sharma et al. (2017) find there is a longer audit lag in the year of a partner rotation, suggesting more audit effort. This is supported by Ferguson et al. (2017) who document an increased audit lag for clients who rotate audit partners in Australia. In our setting, we predict a greater audit lag for rotations before the annual report audit, as they are more likely to represent unplanned rotations which should result in greater audit effort required in the annual report audit. Alternatively, reviewing the interim review could allow the identification of more issues that require more work at the annual report which would also increase the audit lag. As our study considers the interim review, we also run tests on the interim review lag (the number of days from the end of the half-year financial period to the interim review report date). Rotations before the annual report audit should have no effect on the interim review lag as the partner at that point is unchanged. Equally, if the interim review provides a training opportunity for the new partner, then rotations before the interim review would be more likely to increase only the interim review lag. Last, if both types of partner rotations increase the audit lag then it would suggest both have similar effects on increasing audit effort. Due to the competing explanations we state this as two sub-hypotheses: 
H2a: Annual report lag is associated with partner rotations that occur before the annual audit.

H2b: Interim report lag is associated with partner rotations that occur before the interim review

\section{RESEARCH DESIGN}

\section{Model specification}

Our primary analysis uses an audit fee model with fee determinants drawn from prior literature (e.g., Hay et al., 2006) and a binary variable to examine partner rotations. We run our OLS regression on the audit fee reported in the annual report since fees for the interim review are typically not reported separately. We specify the following regression model, including year and industry fixed effects (time and firm subscripts omitted for convenience):

$$
\begin{aligned}
& \text { LnAF }=\beta_{0}+\beta_{1} \text { Rotation }+\beta_{2} \text { LnTA }+\beta_{3} \text { SqrtSub }+\beta_{4} \text { Foreign }+\beta_{5} \text { Current }+\beta_{6} D E+ \\
& \beta_{7} \text { ROA }+\beta_{8} \text { Loss }+\beta_{9} Y E+\beta_{10} \text { CEOChair }+\beta_{11} \text { IndepDir }+\beta_{12} \text { Big } 4+\beta_{13} \text { Modified }+ \\
& \beta_{14} \text { LnNAS }+\beta_{15} \text { CityCost }+\beta_{16} \text { TenureDum }+\beta_{17} \text { Initial }+\varepsilon
\end{aligned}
$$

All variables are defined in Table 1. Our variable of interest is Rotation which tests whether audit fees varied during the year of an audit partner rotation. ${ }^{11} \mathrm{We}$ extend prior literature by replacing the Rotation variable, with RotationAudit and RotationReview which represent whether the rotation occurred before the annual report audit or the interim review. Thus if H1 is supported we expect RotationReview to be significantly positive. We select our control variables based on prior literature (e.g., Hay et al., 2006; Causholli et al., 2010). In a

\footnotetext{
${ }^{11}$ Rotation captures both mandatory and voluntary partner rotations, where the former (latter) involves the partner in the year prior to rotation serving equal or more (less) than five years on the engagement (Lennox et al., 2014; Stewart et al., 2016). We control for whether these classifications yield differences with TenureDum, a dummy variable for when rotation is mandatory.
} 
meta-analysis of published studies, Hay et al. (2006) found that client size is the most important determinant of audit fees, thus we expect a positive sign on LnTA. We also expect the square root of the number of subsidiaries $(S q r t S u b)$ and the proportion of subsidiaries that are foreign (Foreign) to be significantly positive. Client risk and complexity are associated with higher audit fees (Simunic, 1980; Dickens et al., 2008); therefore, we expect a negative (positive) association between audit fees and Current (DE), ROA and Loss. Firms with a peak financial year end $(Y E)$ should have higher audit fees. The corporate governance characteristics of the client are controlled for by including the proportion of independent directors (IndepDir), and whether the CEO is also the chair of the board of directors (CEOChair). ${ }^{12}$ We do not predict the direction of any association between audit fees and corporate governance (Tsui et al., 2001; Carcello et al., 2002). Next, we control for the effect of any Big4 fee premium (Simunic, 1980; Hay et al., 2006). We expect firms with adverse opinions (Modified) (Davis et al., 1993; Schelleman \& Knechel, 2010) and greater non-audit services $(\operatorname{LnNAS)}$ to have higher audit fees (Turpen, 1990). We control for the differential cost of conducting audits across offices with CityCost, a dummy variable taking the value of one if the audit office is based in Sydney or Melbourne. Following prior literature (Lennox et al., 2014; Stewart et al., 2016), we control for mandatory rotations with TenureDum, a dummy variable equal to one if mandatory partner rotation takes place, where a client undertakes a partner rotation and had the same audit partner in the previous year for at least five consecutive audits or five of the last seven audits. ${ }^{13} \mathrm{We}$ also control for initial audit firm engagements with Initial, a dummy variable taking the value of one if the client is audited by

\footnotetext{
${ }^{12} \mathrm{We}$ do not control for the presence of an audit committee as ASX listing rules require the largest 500 companies to have an audit committee.

${ }^{13}$ Australian requirements between 2007 and 2012 state that individuals cannot be the audit or review partner in the audit of a listed entity for more than five successive years or for more than five out of seven successive years (see ASIC Regulatory Guide 187). Following the 2012 amendment by the Treasury of Australia (2012), an individual can remain as the audit or review partner for a further two years for a total of seven years with approval from the client's audit committee (see Corporations Act s324DAA).
} 
different audit firm from the previous year (Simunic, 1980; DeAngelo, 1981; Magee \& Tseng, 1990; Craswell \& Francis, 1999).

To test Hypotheses $2 \mathrm{a}$ and $2 \mathrm{~b}$ we respecify equation (1), replacing $\operatorname{LnAF}$ with the square root of the difference in days between the financial year-end date and the reported signing of the annual report audit opinion (SqrtARLag) and square root of the difference in days between the interim half year-end date and the reported signing date of the interim financial statements review conclusion (SqrtINTLag). If the audit lag and RotationAudit or RotationReview are significantly associated with each other, it will provide evidence on how the timing of rotation increases audit effort. Any changes in audit effort surrounding rotations will also provide insight into the cause of the audit fee results.

\section{Sample}

We collect data on the 500 largest ASX listed companies during the years 2007 to 2014 . Firms are included in the sample for the whole period even if they were not in the largest 500 firms every year. Annual report audit data are obtained from SIRCA, financial data from Aspect Huntley and any missing data are supplemented by hand collection. We then download all interim financial statements and hand-collect the relevant assurance data for the review. ${ }^{14}$ As we are interested in changes in audit partners, we require firms to have available data across the whole sample period to be included in the sample. To ensure all annual reports and interim financial statements are six months apart we remove any firms with financial year end changes from the sample. Finally, we exclude all firms in the financial industry (GICS 40) given differences in financial reporting requirements (Simunic, 1980; Carson et al., 2012). This results in a final sample 3,480 firm-year observations consisting of 566 unique firms.

\footnotetext{
${ }^{14}$ The interim review typically does not disclose fees paid to the audit firm for the review.
} 
The sample composition by partner rotation timing and two-digit GICS industry sector are shown in Table 2. Panel A of Table 2 shows that 769 partner rotations take place in the sample, with 655 (85 percent) occurring before the interim review and 114 (15 percent) before the annual report audit. This is consistent with auditors preferring rotations to commence at the interim review, which serves as a 'training ground' to prevent disruptions in the arguably more important annual report audit (Sanders et al., 2009). Thus, we provide descriptive evidence on the functioning of the audit market by showing that the majority of partner rotations occur before the interim review; however rotations before the annual report audit are still a sizable minority. Panel B of Table 2 shows that the sample is weighted to the resource sector, with 45 percent of the sample in either the energy (15 percent) or materials sectors (30 percent), and relatively few observations in the utilities (1 percent), telecommunication (3 percent) or consumer staples ( 5 percent) sectors.

\section{RESULTS}

\section{Descriptive statistics}

Table 3 presents sample statistics for the full sample $(n=3,480)$ and a univariate comparison of the partner rotation $(n=769)$ and non-partner rotation subsamples $(n=2,711)$. Panel A of Table 3 presents the descriptive statistics for continuous variables. We find the mean audit fee, which includes both statutory annual report and interim report audit fees, is $\$ 630,710$ with a large range from $\$ 3,730$ to $\$ 54,300,000$. The logarithmic transformation of audit fees, $L n A F$, is not significantly different between the rotation sample and non-rotation sample suggesting partner rotations, irrespective of timing, do not have a clear directional impact on audit fees when other factors are not controlled for. When considering audit reporting lag, we find the average annual report lag $(A R L a g)$ is 68.64 days, which is almost 13 days longer than the interim reporting lag (INTLag) of 56.10 days. This timing difference is consistent with 
less effort being expended upon the interim review compared to the annual audit (Ettredge et al., 1994, 2000; Chen et al., 2007). Univariate comparisons for the square root of ARLag (SqrtARLag) and INTLag (SqrtINTLag) are insignificant for mean and median tests. While this suggests that partner rotations do not impact annual or interim reporting lag, this does not account for the fact that partner rotations taking place at the interim (annual) engagement may have no increase in reporting lag at the annual (interim) engagement. Consistent with the large range in audit fees, there is a large variation in total assets $(\$ 100,000$ to $\$ 161,000,000)$ and subsidiaries (0 to 1,187). There are no significant differences for any control variables between the partner rotation and non-partner rotation companies. This suggests there are not inherent differences in risk and complexity for firm-year observations with a partner rotation. ${ }^{15}$ To prevent outlying observations influencing our results, we winsorise all continuous variables at the $1^{\text {st }}$ and $99^{\text {th }}$ percentiles. ${ }^{16}$

Panel B of Table 3 reports descriptive statistics for binary variables. Our sample comprises 769 (22 percent) partner rotations, similar to the 23 percent reported by Stewart et al. (2016). Additionally, TenureDum shows that 369 (47 percent) partner rotations take place after five years of tenure from the outgoing partner and would represent mandatory partner rotation. Thus, the remaining 400 (53 percent) partner rotations constitute voluntary partner rotations. In terms of our other variables of interest, 71 percent of the sample is audited by a Big 4 firm, consistent with prior research noting high concentration in the Australian audit market in the larger client segment (Carson et al., 2012; Ferguson \& Scott, 2014).

In Table 4, we consider whether there are differences in the characteristics of companies that rotate partners before the interim review $(n=655)$ or annual report audit

\footnotetext{
15 There are also no differences in the year before rotation. These results provide some evidence that endogeneity does not appear to drive any of the results found.

${ }^{16}$ Given the potential for outlying observations influencing the results despite winsorizing all continuous variables, we also re-run our analysis after excluding observations with absolute studentized residuals exceeding 3 (untabulated) consistent with prior literature (Reichelt and Wang, 2010). The results remain qualitatively similar to those reported in the paper.
} 
$(n=114)$. Panel A of Table 4 reports continuous variables, with $t$-tests and Mann-Whitney tests showing that firms rotating before the interim review (RotationReview) have significantly $(p<0.05)$ higher audit fees, and are generally larger and more complex in terms of total assets and the number of subsidiaries compared to firms rotating before the annual audit (RotationAudit). Despite this, firms rotating before the annual audit (RotationAudit) experience weakly significantly $(p<0.1)$ greater annual audit reporting lag, while firms rotating before the interim review (RotationReview) do not have higher interim review reporting lag. Rotations taking place after five years of partner tenure (TenureDum) overwhelmingly occur at the interim review (365 to 4). In terms of other differences, firms that rotate before the interim review (RotationReview) are on average more profitable (ROA). Considering the differences in the characteristics we leave our formal discussion of the effect of rotation timing on audit fees to our multivariate analysis.

Table 5 reports a correlation matrix for our regression variables. We report Pearson (Spearman) correlations above (below) the diagonal. Pearson correlations provide supporting evidence for our hypothesis as RotationReview is significantly positively associated with LnAF, whilst RotationAudit is negative. Furthermore, RotationAudit is positively associated with SqrtARLag which suggests such rotations result in greater audit effort during the annual report audit. Consistent with expectations, the highest correlations between continuous variables are between $L n A F$ and LnTA. As the highest Pearson correlation between control variables is between LnTA and SqrtSub (Pearson=0.67, Spearman=0.65), we conclude that multicollinearity is unlikely to be a major concern.

\section{Audit fee regression results}

Table 6 presents our main regression results, with the natural logarithm of audit fees $(L n A F)$ as the dependent variable and our variables of interest being the occurrence (Rotation) and 
timing (RotationReview and RotationAudit) of rotations. The models appear to be robust with the base model having an adjusted $\mathrm{R}^{2}$ of 83.9 percent, and the highest variance inflation factor of 3.09 on LnTA suggesting multicollinearity is not a major issue. Although it is not the focus of this study, Table 6 shows that most control variables are consistent with our expectations. In particular, there is strong evidence of a Big 4 audit fee premium and higher audit fees for larger (LnTA), more complex (SqrtSub and Foreign) and risky (Modified) firms.

In Column (1) of Table 6, we run our base model where our variable of interest is Rotation and find that partner rotation is not significantly associated with audit fees. This is unexpected given prior evidence showing that audit fees are significantly higher at partner rotation (Stewart et al., 2016; Ferguson et al., 2017), but could be attributable to having a longer sample period, where learning effects may reduce the disruption of partner rotation or our sample composition skewing to larger and mid-sized clients. However, when we disaggregate partner rotation based on the timing (i.e. interim review or annual audit) in Column (2) of Table 6, we find that RotationReview is positive and significantly $(p<0.05)$ associated with audit fees, supporting H1. ${ }^{17}$ Thus, firms who experience a partner rotation before the interim review are pay 7.14 percent higher audit fees, or $\$ 45,055$ on the average audit fee compared to a non-rotation firm. ${ }^{18}$ Next we rerun our regressions on only observations with a partner rotation in Column (3) to rule out results being driven by differences between the rotation and non-rotation observations. Consistent with expectations, we find that rotations occurring before the interim review are positive and significantly $(p<0.05)$ associated with audit fees. Firms rotating before the interim review pay 11.96

\footnotetext{
17 The coefficients for RotationReview and RotationAudit are significantly different $(p<0.01)$.

${ }^{18}$ The equation used for measuring the relative increase in fees is $\left(\mathrm{e}^{\mathrm{z}}-1\right)$, where $\mathrm{z}$ is the coefficient value denoting the intercept shift. The average audit fee for the sample of firms is $\$ 630,710$, resulting in an average fee effect of $\$ 45,055$.
} 
percent higher audit fees than firms rotating their audit partner before the annual report, which results in a fee difference of $\$ 75,453$ on the average audit.

Next, we partition the sample into whether clients have high or low bargaining power, based on the relative dependence of the audit firm on fees from the client. Accordingly, we define bargaining power (Power) as the audit fees of the client scaled by the sum of audit fee from all clients of the auditor's office conducting the audit, where clients with high (low) bargaining power have Power above (below) the median. The results for the high and low bargaining power subsamples are reported Columns (4)-(5) and Columns (6)-(7) of Table 6 respectively. We find that while Rotation and RotationReview are insignificant in the high bargaining power subsample, RotationAudit is negative and significantly $(p<0.05)$ associated with audit fees. We interpret this as showing that as rotations before the annual report audit are more likely to be unplanned, the audit firm would have a weaker bargaining position. Thus, clients with high bargaining power are able to exploit this position and obtain discounts or alternatively, auditors partly write-off the audit fee for these more economically important clients.

For clients with low bargaining power, Column (6) of Table 6 shows that Rotation is positive and significantly $(p<0.01)$ associated with audit fees; with Column (7) showing that the effect is isolated to rotations occurring at the interim review (RotationReview). Therefore, we interpret our results as showing that audit firms only charge a fee premium (discount) or pass on (absorb) the costs of partner rotation when they have a stronger (weaker) relative client-auditor bargaining position. These results build on Stewart et al. (2016), who find higher fees in the year of partner rotation by showing that the fee premium is dependent on the timing of the partner rotation and level of client bargaining power. This provides further insight to prior literature, where studies were unable to discern between partner rotations 
based on the timing and did not consider differential bargaining power between clients (Stewart et al., 2016; Sharma et al., 2017; Ferguson et al., 2017).

In Table 7, we consider other factors impacting our results. First, we examine whether our result holds for partner rotations that are voluntary. ${ }^{19}$ Unlike mandatory partner rotations that are planned based on partner tenure and almost exclusively occur at the interim review, voluntary partner rotations can be both planned and unplanned (Dodgson et al., 2017). ${ }^{20}$ To consider whether the effect persists for voluntary partner rotations, we isolate voluntary rotations by interacting RotatationReview and RotatationAudit with VPR, defined as a binary variable taking the value of one if the audit report is signed by a different partner than in the previous year, where there is no change in audit firm and the previous partner had a tenure of less than five years. Columns (1)-(3) of Table 7 present the results for the full sample, and high and low bargaining power samples respectively. For the full sample (Column (1)), we find that voluntary partner rotations occurring before the interim review are positive and significantly $(p<0.05)$ associated with audit fees. When partitioning by client bargaining power, consistent with our main results, voluntary partner rotations occurring before the interim review (annual report) are positive (negative) and associated with audit fees when there is low (high) bargaining power at the $1 \%(5 \%)$ level of confidence.

Next we examine whether the results differ based on auditor or client size. When partitioning by auditor size in Columns (4)-(5) of Table 7, we find rotations occurring at the interim review are positive and significantly $(p<0.05)$ associated with audit fees for Big 4 clients, while rotations at the annual audit are negative and significantly $(p<0.01)$ associated with audit fees for non-Big 4 clients consistent with these smaller suppliers having less bargaining power. When partitioning by client size in Columns (6)-(7) of Table 7, we find

\footnotetext{
${ }^{19} \mathrm{We}$ also consider the isolated effect of mandatory partner rotation, of which almost exclusively occur at the interim review, and find higher audit fees for mandatory partner rotations involving non-Big 4 auditors (Sharma et al., 2017; Ferguson et al., 2017).

${ }^{20}$ Given mandatory partner rotations overwhelmingly occur at the review (99\%), we are unable to make meaningful comparisons of whether rotation timing differs for these rotations.
} 
rotations taking place before the annual audit are negative and weakly significantly $(p<0.1)$ associated with audit fees for large clients, while rotations at the interim review are positive and significantly $(p<0.01)$ associated with audit fees for smaller clients. This outcome is consistent with the size of the client capturing their economic influence and bargaining power.

Our results are thus broadly consistent with both Stewart et al. (2016) and Ferguson et al. (2017) in showing higher audit fees for smaller clients partaking in partner rotation. We build on their studies by showing the effect is isolated to rotations at the interim review. However, as Stewart et al. (2016) and Ferguson et al. (2017) report opposing results for rotation in the larger client segment, our results suggest that the difference in findings may be attributable to rotations before the annual audit resulting in lower audit fees.

\section{Audit reporting lag regression results}

Next, we consider the effect of rotation on audit effort by examining whether the audit reporting lag differs based on when the rotation occurs. As our study incorporates an analysis of interim review reporting lag, we are able to analyse the relative increase in effort at each assurance engagement to determine the timing of the learning effects of rotation. Table 8 reports our audit reporting lag regression results. In regards to our control variables, we find broadly consistent and intuitive results for both the annual report and interim lag with smaller (LnTA), more risky (Loss) and weaker governed (IndepDir and CEOChair) firms with more reporting issues (Modified) associated with a longer audit reporting lag. Thus, we also demonstrate that the interim lag has similar determinants in the Australian setting, expanding to the existing literature on conducting a timely review (Ettredge et al., 1994, 2000).

The result in Column (1) of Table 8 shows rotations are not associated with the annual report audit lag (SqrtARLag); however, Column (2) shows rotations occurring before the 
annual audit are positive and significantly $(p<0.05)$ associated with the annual audit reporting lag (SqrtARLag). This result suggests that a rotation occurring before the annual report audit will add an extra 1.57 days to the average annual audit. ${ }^{21}$ Rotations are positive and weakly significantly $(p<0.1)$ associated with the interim reporting lag (SqrtINTLag), with the results driven by rotations occurring before the review and not the annual audit (Columns (3) and (4)). As we find evidence of significantly higher (lower) fees for rotations at the interim review (annual audit), our audit reporting lag results suggest that this is not driven by differential audit effort or the audit partner identifying issues that require more work at the annual report audit (i.e. the costs of partner rotation) but rather differences in bargaining power when rotations are either planned or unplanned. This finding expands on Sharma et al. (2017) by showing that planned rotations occurring at the interim review allows for timelier audit reporting at the annual report.

\section{Robustness tests}

Our multivariate analyses are also robust to a variety of untabulated sensitivity tests. First, we rerun our regressions using total fees paid to the auditor, and the results remained unchanged. Although we control for year effects in our main analyses, we also remove observations from 2008 to control for any effects of the Global Financial Crisis (Xu et al., 2013) and find unchanged results. Our results are similar when we exclude major industries (energy and materials) that have quarterly cash flow reporting requirements, although such reports are without assurance. We take the natural logarithm or inverse sine of all financial ratios (adjusted to allow transformation) to control for the non-normal distribution of tails (Ashton et al., 2004; Ataullah et al., 2007). As we find consistent results, our main inferences are

\footnotetext{
${ }^{21}$ The equation used for measuring the relative increase in audit lag given a square root transformation of the dependent variable is $\left(\mathrm{z}^{2}\right)$, where $\mathrm{z}$ is the coefficient value denoting the intercept shift. Thus, the RotationAudit coefficient squared suggests a 2.28 percent increase in ARLag. The ARLag for the average sample firm is 68.64 days.
} 
unlikely to be driven by 'fat' tails. Results are also unchanged when we deflate audit fees based on yearly Consumer Price Index (CPI) rates at 30 June reported by the Australian Taxation Office.

Given the concern that fee models may be biased by audit firm changes, our results are robust to excluding observations that have changed audit firms (Initial). We also consider the effect of long audit firm tenure on our results by specifying LFTEN, a binary variable equal to one if the client has retained the same audit firm on the engagement for 7 years or more, and 0 otherwise. ${ }^{22}$ When including $L F T E N$, we find the variable is not significantly associated with audit fees. The results do not change when we interact LFTEN with Rotation, RotationReview or RotationAudit, and as all interaction terms are insignificant it suggests that familiarity between the audit firm and client does not mitigate the pricing effects of rotation (Sharma et al., 2017). Our results also do not differ when using the natural logarithm of audit firm tenure.

We consider whether there are different audit fees in the two years before and after rotations before the interim review and annual report audit (Stewart et al., 2016; Sharma et al., 2017). We find that neither the two years prior nor the two years following rotation are associated with audit fees and our primary variables of interest remain qualitatively the same suggesting these effects are rotation year specific. As one concern could be that the costs of rotation before the annual report audit may only be priced in the following year given its more likely unforeseen nature, the lack of a higher audit fee in the year following RotatationAudit provides further support that our results are driven by the bargaining power argument. $^{23}$

\footnotetext{
${ }^{22}$ Given limited historical data on Australian firms, our estimation of audit firm tenure commences from 2000, meaning 7 years is the longest tenure that can be identified consistently for engagements across all years (i.e. with the sample starting in 2007).

${ }^{23}$ This is based on the possibility that the costs of rotation for rotations occurring at the annual audit are unexpected, and therefore not budgeted or priced into the current year's reported audit fee but instead incorporated into the subsequent year's reported audit fee. Based on prior literature (Bedard et al., 2008; Bedard
} 
One concern with our study is endogeneity arising from self-selection in rotation firms. Our univariate comparison of rotation and non-rotation firms suggests no differences are evident in variables measuring risk, which alleviates the extent of the potential bias. Similarly, our regression residuals are not significantly associated with our independent variables of interest (timing of audit partner rotation).As we are unable to identify a valid instrumental variable we do not run a two-stage least model. However, we are able to conduct a firm fixed effects model to control for within firm variations and find that the results remain unchanged from the primary analysis.

\section{CONCLUSION}

There is a substantial body of literature that documents the functioning of the audit market, including partner rotations. We add to prior literature that finds a fee premium around partner rotations (Stewart et al., 2016; Sharma et al., 2017; Ferguson et al., 2017), by documenting significantly higher audit fees only when the partner is rotated before the interim review and significantly lower fees when the partner is rotated before the annual audit. We argue that partner rotations before the annual report audit are less likely to be planned, but rather stem from dissatisfaction by the client with their partner or the audit firm managing workloads. Thus audit firms have a weaker client-auditor bargaining position and are less able to pass on the costs of the partner rotation or charge a premium. Consistent with this we find that the higher audit fees for rotations before the interim review only persist in situations where clients hold less bargaining power, as represented by subsamples of client's economic importance to the auditor. Further, we find audit fees are significantly lower by 12.63 percent for rotations before the annual audit when client bargaining power is higher, supporting the view that clients are able to negotiate more favourable engagement terms at the rotation. to be priced into the current year's audit fee. We thank the reviewer for raising this possibility. 
Analysis of audit reporting lag at the interim review and annual audit shows delays from both rotations before interim reviews and annual audits at their respective engagements suggesting the pricing effect is not driven by differential effort applied.

We contribute to the extant literature and to policy debate on partner rotation in the following ways. As regulators have long expressed concern that long-term auditor-client relationships may affect auditor independence (e.g., ICAEW, 2002; PCAOB, 2011; Treasury of Australia, 2012; Crowe Horwath, 2012) and audit partner rotation has been suggested as a low cost solution, our results provide a better understanding of the costs borne by clients and auditors based on the pricing of audit engagements. In particular, our findings suggest the costs of rotation are absorbed by parties holding less bargaining power in the auditor-client relationship. These results are also of interest to academics and regulators who are interested in whether the benefits of partner rotation outweigh the costs as they suggest that the net benefits/costs differ based on the timing of the rotation. More generally, we also expand the literature on the effect of timing on the outcomes observed at auditor changes that has largely focused on audit firm switches (Schwartz \& Soo 1996; Cassell et al., 2017; Pacheco-Paredes et al., 2017).

Our paper is subject to a number of limitations. First we can only infer the cost of rotation through audit fees, as actual costs are not publically available. Furthermore, the audit fee is a function of both costs and the audit firm's pricing strategy. Second, we use a change in the identified partner that signed the audit report as a proxy for a change in audit partner. It is unobservable to us whether the old or new partner carried out the majority of the engagement. Furthermore, as our study identifies that the cost of partner rotation is dependent on the situation, but does not explore the practical implications of this cost, future audit research could use a case or interview methodology to explore planning around rotations. Third, our study uses data from the Australian setting and considers interim assurance 
engagements. Our results may not be generalizable to other jurisdictions where interim financial statements have different assurance requirements. Finally, we concede that partner rotations are subject to endogeneity although our empirical results suggest that the issue is not severe.

Our paper also highlights a fruitful area of future audit research: the assurance of interim financial statements. Interim financial statements are an important source of news, however their assurance and interplay with the annual report audit have been paid scant attention relative to the substantial body of work on the annual report audit. Specifically, we highlight the effect of interim assurance on audit market structure and pricing, the importance of interim review lag, the effect of interim assurance on overall audit quality, the difference in quality between audits and reviews and the value of interim review conclusions. 


\section{REFERENCES}

Ashton, D., Dunmore, P. \& Tippett, M. (2004), 'Double entry bookkeeping and the distributional properties of a firm's financial ratios', Journal of Business Finance and Accounting, Vol. 31, No. 5, pp. 583-606.

Ashton, R., Wilingham, J. \& Elliott, R. (1987), 'An empirical analysis of audit delay', Journal of Accounting Research, Vol. 25, No. 2, pp. 275-92.

Ashton, R., Graul, P. \& Newton, J. (1989), 'Audit delay and the timeliness of corporate reporting', Contemporary Accounting Research, Vol. 5, No. 2, pp. 657-73.

Ataullah, A., Higson, A. \& Tippett, M. (2007), 'The distributional properties of the debt to equity ratio: Some implications for empirical research', Abacus, Vol. 43, No. 2, pp. 111-35.

Australian Securities and Investments Commission (ASIC). (2014), Information Sheet 106: Audit quality: The role of directors and audit committees. Available at: http://asic.gov.au/regulatory-resources/financial-reporting-and-audit/auditors/auditquality-the-role-of-directors-and-audit-committees

Bamber, E, Bamber, L. \& Schoderbek, M. (1993), 'Audit structure and other determinants of audit report lag: An empirical analysis', Auditing: A Journal of Practice \& Theory, Vol. 12, No. 1, pp.1-23.

Bédard, J. C., Ettredge, M. L., \& Johnstone, K. M. (2008). Fee pressure and the longitudinal dynamics of audit engagement budgeting and reporting. Advances in Accounting, Vol. 24, No. 1, pp. 32-40.

Bédard, J. \& Johnstone, K. (2010), 'Audit partner tenure and audit planning and pricing', Auditing: A Journal of Practice \& Theory, Vol. 29, No. 2, pp. 45-70.

Bédard, J. \& Courteau, L. (2015), 'Benefits and costs of auditor's assurance: Evidence from the review of quarterly financial statements', Contemporary Accounting Research, Vol. 32, No. 1, pp. 308-35.

Carey, P. \& Simnett, R. (2006), 'Audit partner tenure and audit quality', The Accounting Review, Vol. 81, No. 3, pp. 653-76.

Carson, E., Fargher, N., Simon, D. \& Taylor, M. (2004), 'Audit fees and market segmentation - Further evidence on how client size matters within the context of audit fee models', International Journal of Auditing, Vol. 8, No. 1, pp. 79-91.

Carson, E., Simnett, R., Soo, B. \& Wright, A. (2012), 'Changes in audit market competition and the Big N premium', Auditing: A Journal of Practice \& Theory, Vol. 31, No. 3, pp. 47-73.

Carcello, J., Hermanson, D., Neal, T. \& Riley Jr, R. (2002), 'Board characteristics and audit fees', Contemporary Accounting Research, Vol. 19, No. 3, pp. 365-85.

Cassell, C., Hansen, J., Myers, L. \& Seidel, T. (2016), 'Does the timing of auditor changes affect audit quality? Evidence from the initial year of the audit engagement', Available at: http://ssrn.com/abstract=2374162

Causholli, M., DeMartinis, M., Hay, D. \& Knechel, W. (2010), 'Audit markets, fees, and production: Towards an integrated view of empirical audit research', Journal of Accounting Literature, Vol. 29, pp. 167-215.

Chen, C.-Y., Lin, C.-J. \& Lin, Y.-C. (2008), 'Audit partner tenure, audit firm tenure, and discretionary accruals: Does long auditor tenure impair earnings quality?', Contemporary Accounting Research, Vol. 25, No. 2, pp. 415-45.

Chen, L., Carson, E. \& Simnett, R. (2007), 'Impact of stakeholder characteristics on voluntary dissemination of interim information and communication of its level of assurance', Accounting \& Finance, Vol. 47, No. 4, pp. 667-91. 
Chi, W. \& Huang, H. (2005), 'Discretionary Accruals, Audit-Firm Tenure and Audit Partner Tenure: Empirical Evidence from Taiwan', Journal of Contemporary Accounting \& Economics, Vol. 1, No. 1, pp. 65-92.

Chi, W., Huang, H., Liao, Y. \& Xie, H. (2009), 'Mandatory audit partner rotation, audit quality, and market perception: Evidence from Taiwan', Contemporary Accounting Research, Vol. 26, No. 4, pp. 359-91.

Commonwealth of Australia (2004), Corporate Law Economic Reform Program (Audit Reform and Corporate Disclosure) Act 2004. Canberra, Australia.

Craswell, A. \& Francis, J. (1999), 'Pricing initial audit engagements: A test of competing theories', The Accounting Review, Vol. 74, No. 2, pp. 201-16.

Crowe Horwath. (2012), Audit Firm Rotation - A good or bad proposal? http://www.crowehorwath.net/crowe-horwath-global/insights/insights assets/audit_firm_rotation_\%E2\%80\%93_a_good_or_bad_proposal_.aspx

DeAngelo, L. (1981), 'Auditor independence, 'low balling', and disclosure regulation', Journal of Accounting \& Economics, Vol. 3, No. 2, pp. 113-27.

Davis, L., Ricchiute, D. \& Trompeter, G. (1993), 'Audit effort, audit fees, and the provision of nonaudit services to audit clients', The Accounting Review, Vol. 68, No. 1, pp. 135-50.

Dodgson, M. K., Agoglia, C. P., Bennett, G. B., \& Cohen, J. R. (2017). Managing the auditor-client relationship through partner rotations: The experiences of audit firm partners.

Ettredge, M., Simon, D., Smith, D. \& Stone, M. (1994), 'Why do companies purchase timely quarterly reviews?', Journal of Accounting \& Economics, Vol. 18, No. 2, pp. 131-55.

Ettredge, M., Simon, D., Smith, D. \& Stone, M. (2000), 'The effect of the external accountant's review on the timing of adjustments to quarterly earnings', Journal of Accounting Research, Vol. 38, No. 1, pp. 195-207.

Fargher, N., Lee, H.-Y. \& Mande, V. (2008), 'The effect of audit partner tenure on client managers' accounting discretion', Managerial Auditing Journal, Vol. 23, No. 2, pp. $161-86$.

Ferguson, A., Lam P. \& Ma, N. (2017), 'Further evidence on mandatory partner rotation and audit pricing: A supply-side perspective', Accounting \& Finance (forthcoming).

Ferguson, A. \& Scott, T. (2014), 'What if there were three? Audit pricing within the Big 4 and the PricewaterhouseCoopers' premium in the Australian audit market', International Journal of Auditing, Vol. 18, No. 1, pp. 57-67.

Hay, D., Knechel, W. \& Wong, N. (2006), 'Audit fees: A meta-analysis of the effect of supply and demand attributes', Contemporary Accounting Research, Vol. 23, No. 1, pp. 141-91.

Higgins, S., Lont, D. \& Scott, T. (2016), 'Longer term audit costs of International Financial Reporting Standards and the differential impact of implied auditor cost structures', Accounting \& Finance, Vol. 56, No. 1, pp. 165-203.

Houghton, K., Ng, J., Jubb, C., \& Kend, M. (2013), The future of audit: keeping capital markets efficient (p. 700). ANU Press.

Knechel, W. \& Payne, J. (2001), 'Additional evidence on audit report lag', Auditing: A Journal of Practice \& Theory, Vol. 20, No. 1, pp. 137-46.

Knechel, W. \& Vanstraelen, A. (2007), 'The relationship between auditor tenure and audit quality implied by going concern opinions', Auditing: A Journal of Practice \& Theory, Vol. 26, No. 1, pp. 113-31. 
Krishnan, J. \& Zhang, Y. (2005), 'Auditor litigation risk and corporate disclosure of quarterly review report', Auditing: A Journal of Practice \& Theory, Vol. 25, No. S-1, pp. 115-38.

Laurion, H., Lawrence, A., \& Ryans, J. P. (2017). US audit partner rotations. The Accounting Review, Vol. 92, No. 3, pp. 209-237.

Lennox, C., Wu, X. \& Zhang, T. (2014), 'Does mandatory rotation of audit partners improve audit quality?', The Accounting Review, Vol. 89, No. 1, 1775-803.

Litt, B., Sharma, D., Simpson, T. \& Tanyi, P. (2014), 'Audit partner rotation and financial reporting quality', Auditing: A Journal of Practice \& Theory, Vol. 33, No. 3, pp. 5986.

Magee, R. \& Tseng, M. (1990), 'Audit pricing and independence', The Accounting Review, Vol. 65, No. 2, pp. 315-36.

Pacheco-Paredes, A. A., Rama, D. V., \& Wheatley, C. M. (2017). The timing of auditor hiring: Determinants and consequences. Accounting Horizons, Vol. 31, No. 3, pp. 85 -103 .

Public Company Accounting Oversight Board (PCAOB). (2011), Concept Release on Auditor Independence and Audit Firm Rotation, PCAOB Release No. 2011-006 (August 16), PCAOB Rulemaking Docket Matter No. 37. Available at: https://pcaobus.org/ Rulemaking/Docket037/Release_2011-006.pdf

Reichelt, K.J. and Wang, D. (2010). 'National and office specific measures of auditor industry expertise and effects on audit quality'. Journal of Accounting Research, Vol. 48, no. 3, pp. 647-686.

Ruiz-Barbadillo, E., Gomez-Aguilar, N. \& Carrera, N. (2009), 'Does mandatory audit firm rotation enhance auditor independence? Evidence from Spain', Auditing: A Journal of Practice \& Theory, Vol. 28, No 1, pp. 113-35.

Sanders, C. B., Steward, M. D., \& Bridges, S. (2009). Facilitating knowledge transfer during SOX-mandated audit partner rotation. Business Horizons, Vol. 52, No. 6, pp. 573-82.

Schelleman, C. \& Knechel, W. (2010), 'Short-term accruals and the pricing and production of audit services', Auditing: A Journal of Practice and Theory, Vol. 29, No. 1, pp. 22150 .

Schwartz, K. B., \& Soo, B. S. (1996). The association between auditor changes and reporting lags. Contemporary Accounting Research, Vol. 13, No. 1, pp. 353-370.

Securities and Exchange Commission (SEC), (2001), Revision of commission's auditor independence requirements. Available at: https://www.sec.gov/rules/final/33-7919.htm

Sharma, D., Tanyi, P. \& Litt, B. (2017), 'Costs of mandatory periodic audit partner rotation: Evidence from audit fees and audit timeliness', Auditing: A Journal of Practice \& Theory, Vol. 36, No. 1, pp. 129-49.

Simunic, D. (1980), 'The pricing of audit services: Theory and evidence', Journal of Accounting Research, Vol. 18, No. 1, pp. 161-90.

Stewart, J., Kent, P. \& Routledge J. (2016), 'The association between audit partner rotation and audit fees: Empirical evidence from the Australian market', Auditing: A Journal of Practice \& Theory, Vol. 35, No. 1, pp. 181-97.

Taylor, S. (2011), 'Does audit fee homogeneity exist? Premiums and discounts attributable to individual partners', Auditing: A Journal of Practice \& Theory, Vol. 30, No. 4, pp. 249-72.

Treasury of Australia. (2012), Corporations Legislation Amendment (Audit Enhancement) Bill. Available at: http://www.aph.gov.au/Parliamentary_Business/Bills_Legislation/ Bills_Search_Results/Result?bId=r4764, 21 February 2013.

Tsui, J., Jaggi, B. \& Gul, F. (2001), 'CEO domination, growth opportunities, and their impact 
on audit fees', Journal of Accounting, Auditing and Finance, Vol. 16, No. 3, pp. 189208.

Turpen, R. (1990), 'Differential pricing on auditors' initial engagements: further evidence', Auditing: A Journal of Practice \& Theory, Vol. 9, No. 2, pp. 60-76.

Xu, Y., Carson, E., Fargher, N. \& Jiang, L. (2013), 'Responses by Australian auditors to the global financial crisis', Accounting \& Finance, Vol. 53, No. 1, pp. 301-38. 
Table 1: Variable definitions

\begin{tabular}{|c|c|}
\hline \multicolumn{2}{|r|}{ Dependent Variables } \\
\hline $\operatorname{LnAF}$ & is the natural logarithm of reported audit fees. \\
\hline SqrtARLag & $\begin{array}{l}\text { is the square root of the difference in days between the financial year-end date and the } \\
\text { reported signing of the annual report audit opinion. }\end{array}$ \\
\hline SqrtINTLag & $\begin{array}{l}\text { is the square root of the difference in days between the interim half year-end date and } \\
\text { the reported signing date of the interim financial statements review conclusion. }\end{array}$ \\
\hline \multicolumn{2}{|c|}{ Independent Variables } \\
\hline Rotation & $\begin{array}{l}\text { is a binary variable equal to one if the annual or interim report is signed-off by a } \\
\text { different audit partner than in the previous year and there was no change in audit firm, } \\
\text { and } 0 \text { otherwise. }\end{array}$ \\
\hline RotationReview & $\begin{array}{l}\text { is a binary variable equal to one if a partner rotation occurs with the new partner signing } \\
\text { off for the first time at interim review in year } t \text { and there was no change in audit firm, } \\
\text { and } 0 \text { otherwise. }\end{array}$ \\
\hline RotationAudit & $\begin{array}{l}\text { is a binary variable equal to one if a partner rotation occurs with the new partner signing } \\
\text { off for the first time at annual report audit in year } t \text { and there was no change in audit } \\
\text { firm, and } 0 \text { otherwise. }\end{array}$ \\
\hline BargainingPower & $\begin{array}{l}\text { the audit fees of the client scaled by the sum of audit fees from all clients of the } \\
\text { auditor's office }\end{array}$ \\
\hline$V P R$ & $\begin{array}{l}\text { is a binary variable equal to one if the annual report is signed-off by a different audit } \\
\text { partner than in the previous year, there was no change in audit firm and the previous } \\
\text { partner had less than five years of tenure, and } 0 \text { otherwise. }\end{array}$ \\
\hline \multicolumn{2}{|l|}{ Control Variables } \\
\hline LnTA & is the natural logarithm of total assets. \\
\hline SqrtSub & is the square root of the number of subsidiaries. \\
\hline Foreign & is the ratio of number of foreign subsidiaries to number of subsidiaries. \\
\hline Current & is the ratio of current assets to current liabilities. \\
\hline$D E$ & is the ratio of long term debt to equity. \\
\hline$R O A$ & is the ratio of earnings before interest and tax to total assets. \\
\hline Loss & is a binary variable equal to one if net profit after tax is negative, and 0 otherwise. \\
\hline$Y E$ & is a binary variable equal to one for a 30 June year end, and 0 otherwise. \\
\hline CEOChair & $\begin{array}{l}\text { is a binary variable equal to one if the CEO is also the chairman of the board of } \\
\text { directors, and } 0 \text { otherwise. }\end{array}$ \\
\hline IndepDir & is the percentage of the board of directors that are classified as independent. \\
\hline Big4 & $\begin{array}{l}\text { is a binary variable equal to one if the auditor is Deloitte, Ernst and Young, KPMG or } \\
\text { PwC, and } 0 \text { otherwise. }\end{array}$ \\
\hline Modified & $\begin{array}{l}\text { is a binary variable equal to one if the opinion given was qualified or a going concern } \\
\text { emphasis of matter, and } 0 \text { otherwise. }\end{array}$ \\
\hline $\operatorname{LnNAS}$ & is the natural logarithm of non-audit services. \\
\hline CityCost & $\begin{array}{l}\text { is a binary variable equal to one if the audit office is based in Sydney or Melbourne, and } \\
0 \text { otherwise. }\end{array}$ \\
\hline TenureDum & $\begin{array}{l}\text { is a binary variable equal to one if firm undertakes a partner rotation and has had the } \\
\text { same audit partner for five annual report audits as at } t-1 \text {, and } 0 \text { otherwise. }\end{array}$ \\
\hline Initial & $\begin{array}{l}\text { is a binary variable equal to one if the annual report is audited by a different audit firm } \\
\text { than in the previous year, and } 0 \text { otherwise. }\end{array}$ \\
\hline
\end{tabular}


Table 2: Sample composition by rotation timing and industry classifications

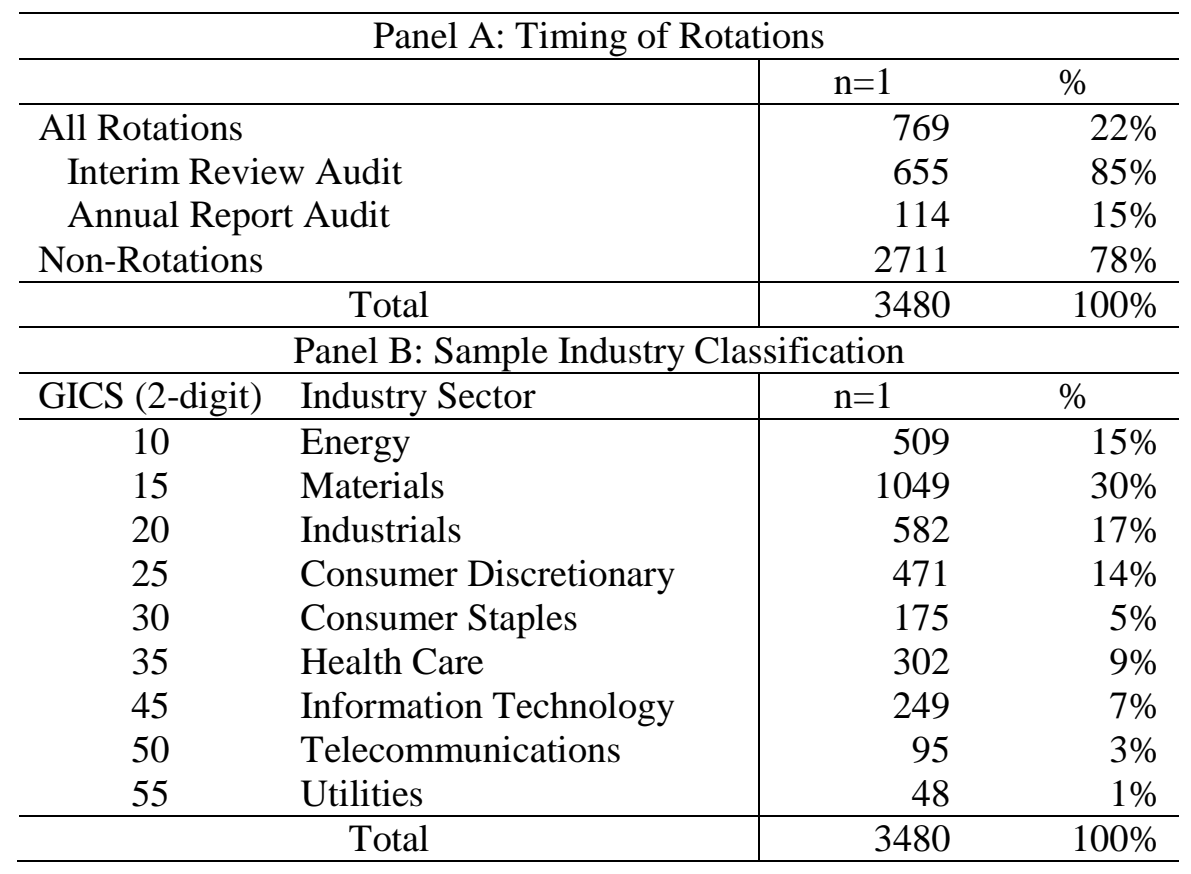


Table 3: Sample statistics and comparison of rotation and non-rotation firms

\begin{tabular}{|c|c|c|c|c|c|c|c|c|c|}
\hline \multicolumn{10}{|c|}{ Panel A: Continuous Variables } \\
\hline Variable & $\mathrm{n}$ & Mean & Median & SD & Min & Max & Mean diff. & $t$-stat & $z$-stat \\
\hline Audit fees $\left(\$^{\prime} 000\right)$ & 3480 & 630.71 & 214.42 & $1,989.82$ & 3.73 & 54,300 & & & \\
\hline $\operatorname{LnAF}$ & 3480 & 12.36 & 12.28 & 1.25 & 8.22 & 17.81 & 0.01 & 1.47 & 1.30 \\
\hline ARLag (days) & 3480 & 68.64 & 64.00 & 17.59 & 24 & 96 & & & \\
\hline SqrtARLag & 3480 & 8.21 & 8.00 & 1.09 & 4.90 & 9.80 & 0.00 & 0.15 & 0.35 \\
\hline INTLag (days) & 3480 & 56.10 & 56.00 & 10.69 & 23 & 76 & & & \\
\hline SqrtINTLag & 3480 & 7.45 & 7.48 & 0.73 & 4.80 & 8.72 & 0.00 & 0.10 & 0.34 \\
\hline$T A(\$ m)$ & 3480 & 1,720 & 211 & 8,590 & 0.10 & 161,000 & & & \\
\hline LnTA & 3480 & 19.28 & 19.17 & 1.84 & 14.73 & 24.73 & 0.02 & 0.84 & 0.61 \\
\hline Subs & 3480 & 24.63 & 10.00 & 52.71 & 0 & 1187 & & & \\
\hline SqrtSub & 3480 & 3.91 & 3.16 & 2.79 & 0 & 13.08 & 0.01 & 0.28 & 0.49 \\
\hline Foreign & 3480 & 0.31 & 0.22 & 0.32 & 0 & 1 & 0.00 & 0.13 & -0.06 \\
\hline Current & 3480 & 4.96 & 1.84 & 9.57 & 0.15 & 77.98 & -0.07 & -0.89 & 0.55 \\
\hline$D E$ & 3480 & 0.38 & 0.18 & 0.63 & 0 & 5.82 & -0.01 & -0.18 & 0.50 \\
\hline$R O A$ & 3480 & -0.07 & 0.03 & 0.34 & -1.98 & 0.41 & 0.01 & 0.73 & 0.96 \\
\hline IndepDir & 3480 & 0.74 & 0.78 & 0.15 & 0 & 1 & 0.01 & 0.64 & 0.58 \\
\hline$N A S\left(\$ \$^{\prime} 000\right)$ & 3480 & 325.35 & 53.26 & 978.53 & 0 & 7,326 & & & \\
\hline LnNAS & 3480 & 9.11 & 10.88 & 4.86 & 0 & 15.81 & 0.08 & 1.89 & 1.75 \\
\hline \multicolumn{10}{|c|}{ Panel B: Binary Variables } \\
\hline Variable & $\mathrm{n}$ & Freq $=1$ & $\%$ & Chi-Square & Variable & $\mathrm{n}$ & Freq $=1$ & $\%$ & Chi-Square \\
\hline Rotation & 3480 & 769 & $22 \%$ & & Big4 & 3480 & 2472 & $71 \%$ & 0.06 \\
\hline RotationReview & 3480 & 655 & $19 \%$ & & Modified & 3480 & 279 & $8 \%$ & 0.01 \\
\hline RotationAudit & 3480 & 114 & $3 \%$ & & CityCost & 3480 & 1774 & $51 \%$ & 0.81 \\
\hline Loss & 3480 & 1446 & $42 \%$ & 0.41 & TenureDum & 3480 & 369 & $11 \%$ & \\
\hline$Y E$ & 3480 & 2815 & $81 \%$ & 0.17 & Initial & 3480 & 237 & $7 \%$ & \\
\hline CEOChair & 3480 & 278 & $8 \%$ & 0.09 & & & & & \\
\hline
\end{tabular}

Table 3 reports sample descriptive statistics and a comparison of partner rotation and non-rotation firms. Mean differences are computed as rotation firms $($ Rotation $=1)$ minus non-rotation firms (Rotation=0). Results from univariate comparison of means ( $t$-stat) and medians ( $z$-stat) for continuous variables are reported for tests of equality of means and Mann-Whitney U tests respectively. Results from comparison of binary variables are reported for Pearson's Chi-Square test. Variables are as defined in Table 1. Twotailed test of significance: $* * *=$ less than $0.01, * *=$ less than 0.05 and $*=$ less than 0.10 
Table 4: Univariate tests of differences between rotation timing

\begin{tabular}{|c|c|c|c|c|c|c|c|}
\hline \multicolumn{8}{|c|}{ Panel A: Continuous Variables } \\
\hline \multirow[b]{2}{*}{ Variable } & \multicolumn{2}{|c|}{ RotationReview } & \multicolumn{2}{|c|}{ RotationAudit } & \multicolumn{3}{|l|}{ Mean } \\
\hline & $\mathrm{N}$ & Mean & $\mathrm{n}$ & Mean & diff. & $t$-stat & $z$-stat \\
\hline $\operatorname{LnAF}$ & 655 & 12.47 & 114 & 12.11 & 0.36 & $2.82 * *$ & $2.93 * * *$ \\
\hline SqrtARLag & 655 & 8.17 & 114 & 8.41 & -0.24 & $-2.39 *$ & $-2.21 * *$ \\
\hline SqrtINTLag & 655 & 7.45 & 114 & 7.52 & -0.07 & -1.02 & -1.20 \\
\hline LnTA & 655 & 19.42 & 114 & 18.8 & 0.62 & $3.20 * *$ & $3.30 * * *$ \\
\hline SqrtSub & 655 & 4.02 & 114 & 3.47 & 0.55 & $2.15^{*}$ & $2.12 * *$ \\
\hline Foreign & 655 & 0.31 & 114 & 0.32 & -0.01 & -0.37 & -0.26 \\
\hline Current & 655 & 4.73 & 114 & 4.51 & -0.22 & 0.27 & -0.44 \\
\hline$D E$ & 655 & 0.39 & 114 & 0.32 & 0.07 & 1.29 & 1.59 \\
\hline$R O A$ & 655 & -0.04 & 114 & -0.14 & 0.1 & $2.08^{*}$ & 1.54 \\
\hline IndepDir & 655 & 0.75 & 114 & 0.74 & 0.01 & 0.74 & 0.62 \\
\hline LnNAS & 655 & 9.44 & 114 & 9.15 & 0.29 & 0.61 & 0.72 \\
\hline \multicolumn{8}{|c|}{ Panel B: Binary Variables } \\
\hline & \multicolumn{3}{|c|}{ RotationReview } & \multicolumn{3}{|c|}{ RotationAudit } & \\
\hline & $\mathrm{N}$ & $\mathrm{n}=1$ & $\%$ & $\mathrm{n}$ & $\mathrm{n}=1$ & $\%$ & $\begin{array}{c}\text { Chi- } \\
\text { Square }\end{array}$ \\
\hline Loss & 655 & 269 & $41 \%$ & 114 & 51 & $45 \%$ & 0.45 \\
\hline$Y E$ & 655 & 531 & $81 \%$ & 114 & 96 & $84 \%$ & 0.70 \\
\hline CEOChair & 655 & 46 & $7 \%$ & 114 & 10 & $8 \%$ & 0.074 \\
\hline Big4 & 655 & 472 & $72 \%$ & 114 & 79 & $69 \%$ & 0.29 \\
\hline Modified & 655 & 52 & $8 \%$ & 114 & 10 & $9 \%$ & 0.13 \\
\hline CityCost & 655 & 354 & $54 \%$ & 114 & 50 & $44 \%$ & 2.16 \\
\hline TenureDum & 655 & 365 & $56 \%$ & 114 & 4 & $4 \%$ & $106.07 * * *$ \\
\hline
\end{tabular}

Table 4 reports a comparison of partner rotations taking at the interim review and annual audit. Mean differences are computed as interim review rotation firms (RotationReview $=1$ ) minus annual audit rotation firms (RotationAudit=1). Results from univariate comparison of means ( $t$-stat) and medians $(z$-stat) for continuous variables are reported for tests of equality of means and Mann-Whitney U tests respectively. Results from comparison of binary variables are reported for Pearson's Chi-Square test. Variables are as defined in Table 1. Two-tailed test of significance: $* * *=$ less than $0.01, * *=$ less than 0.05 and $*=$ less than 0.10 . 
Table 5: Correlation matrix

\begin{tabular}{|c|c|c|c|c|c|c|c|c|c|c|c|c|c|c|c|c|c|c|c|c|c|c|}
\hline & LnAF & $\begin{array}{l}\text { Sqrt } \\
\text { ARLag }\end{array}$ & $\begin{array}{l}\text { Sqrt } \\
\text { INTLag }\end{array}$ & Rotation & $\begin{array}{l}\text { Rotation } \\
\text { Review } \\
\end{array}$ & $\begin{array}{l}\text { Rotation } \\
\text { Audit } \\
\end{array}$ & LnTA & SqrtSub & Foreign & Current & $D E$ & $R O A$ & Loss & $Y E$ & $\begin{array}{l}\text { CEO } \\
\text { Chair } \\
\end{array}$ & $\begin{array}{l}\text { Indep } \\
\text { Dir } \\
\end{array}$ & Big4 & Modified & LnNAS & City Cost & $\begin{array}{l}\text { Tenure } \\
\text { Dum } \\
\end{array}$ & Initial \\
\hline LnAF & & -0.35 & -0.42 & 0.02 & 0.04 & -0.05 & 0.80 & 0.71 & 0.25 & -0.44 & 0.58 & 0.32 & -0.42 & -0.24 & -0.10 & 0.31 & 0.51 & -0.10 & 0.66 & 0.33 & 0.02 & -0.14 \\
\hline SqrtARLag & -0.34 & & 0.54 & 0.00 & -0.02 & 0.04 & -0.34 & -0.22 & -0.05 & 0.11 & -0.27 & -0.31 & 0.32 & 0.11 & 0.11 & -0.23 & -0.24 & 0.24 & -0.23 & -0.16 & -0.01 & 0.08 \\
\hline SqrtINTLag & -0.41 & 0.52 & & 0.00 & -0.01 & 0.03 & -0.39 & -0.30 & -0.05 & 0.20 & -0.34 & -0.37 & 0.39 & 0.14 & 0.13 & -0.24 & -0.24 & 0.21 & -0.31 & -0.23 & -0.02 & 0.09 \\
\hline Rotation & 0.02 & 0.00 & 0.01 & & 0.90 & 0.36 & 0.01 & 0.01 & 0.00 & 0.01 & 0.00 & 0.01 & 0.01 & 0.01 & 0.00 & 0.01 & 0.00 & 0.00 & 0.03 & 0.02 & 0.64 & -0.11 \\
\hline RotatonReview & 0.04 & -0.02 & 0.00 & 0.90 & & -0.09 & 0.03 & 0.02 & 0.00 & 0.00 & 0.02 & 0.03 & 0.00 & 0.00 & -0.01 & 0.01 & 0.01 & 0.00 & 0.03 & 0.03 & 0.71 & -0.13 \\
\hline RotationAudit & -0.05 & 0.04 & 0.03 & 0.36 & -0.09 & & -0.05 & -0.03 & 0.01 & 0.01 & -0.03 & -0.03 & 0.02 & 0.01 & 0.01 & -0.01 & -0.02 & 0.01 & 0.00 & -0.02 & -0.05 & 0.02 \\
\hline LnTA & 0.82 & -0.32 & -0.37 & 0.01 & 0.04 & -0.06 & & 0.65 & 0.05 & -0.37 & 0.59 & 0.35 & -0.42 & -0.24 & -0.08 & 0.33 & 0.39 & -0.17 & 0.58 & 0.20 & 0.03 & -0.13 \\
\hline SqrtSub & 0.73 & -0.19 & -0.28 & 0.00 & 0.02 & -0.03 & 0.67 & & 0.25 & -0.35 & 0.46 & 0.25 & -0.34 & -0.16 & -0.08 & 0.24 & 0.33 & -0.12 & 0.51 & 0.25 & 0.03 & -0.08 \\
\hline Foreign & 0.19 & -0.01 & 0.01 & 0.00 & 0.00 & 0.01 & 0.00 & 0.11 & & -0.01 & 0.06 & -0.03 & 0.04 & -0.09 & -0.02 & 0.03 & 0.12 & 0.05 & 0.13 & 0.07 & 0.01 & -0.02 \\
\hline Current & -0.34 & 0.16 & 0.21 & -0.01 & -0.01 & 0.00 & -0.25 & -0.23 & -0.04 & & -0.48 & -0.20 & 0.29 & 0.12 & 0.05 & -0.10 & -0.21 & -0.11 & -0.28 & -0.16 & 0.02 & 0.01 \\
\hline$D E$ & 0.31 & -0.12 & -0.14 & -0.01 & 0.01 & -0.02 & 0.32 & 0.24 & -0.01 & -0.19 & & 0.30 & -0.40 & -0.12 & -0.07 & 0.19 & 0.27 & -0.11 & 0.42 & 0.15 & 0.01 & -0.08 \\
\hline$R O A$ & 0.28 & -0.25 & -0.24 & 0.01 & 0.03 & -0.06 & 0.43 & 0.21 & -0.07 & -0.08 & 0.06 & & -0.85 & -0.03 & -0.04 & 0.08 & 0.14 & -0.28 & 0.20 & 0.12 & 0.05 & -0.07 \\
\hline Loss & -0.40 & 0.31 & 0.37 & 0.01 & 0.00 & 0.02 & -0.42 & -0.30 & 0.09 & 0.25 & -0.14 & -0.58 & & 0.05 & 0.07 & -0.13 & -0.18 & 0.28 & -0.28 & -0.15 & -0.02 & 0.07 \\
\hline$Y E$ & -0.22 & 0.10 & 0.18 & 0.01 & 0.00 & 0.01 & -0.22 & -0.14 & -0.07 & 0.04 & -0.05 & -0.04 & 0.05 & & 0.03 & -0.19 & -0.22 & -0.01 & -0.16 & -0.10 & 0.01 & 0.05 \\
\hline CEOChair & -0.11 & 0.11 & 0.12 & 0.00 & -0.01 & 0.01 & -0.10 & -0.08 & -0.01 & 0.04 & -0.06 & -0.04 & 0.07 & 0.03 & & -0.17 & -0.04 & 0.06 & -0.08 & 0.00 & 0.02 & 0.02 \\
\hline IndepDir & 0.26 & -0.21 & -0.21 & 0.01 & 0.02 & -0.01 & 0.28 & 0.19 & 0.00 & -0.09 & 0.06 & 0.10 & -0.11 & -0.16 & -0.17 & & 0.23 & -0.06 & 0.27 & 0.09 & 0.00 & -0.06 \\
\hline Big4 & 0.49 & -0.23 & -0.24 & 0.00 & 0.01 & -0.02 & 0.39 & 0.31 & 0.07 & -0.16 & 0.14 & 0.13 & -0.18 & -0.22 & -0.04 & 0.20 & & -0.07 & 0.42 & 0.16 & 0.00 & -0.05 \\
\hline Modified & -0.10 & 0.22 & 0.19 & 0.00 & 0.00 & 0.01 & -0.18 & -0.10 & 0.07 & -0.04 & 0.01 & -0.33 & 0.28 & -0.01 & 0.06 & -0.07 & -0.07 & & -0.10 & -0.05 & 0.00 & 0.05 \\
\hline LnNAS & 0.52 & -0.18 & -0.24 & 0.03 & 0.03 & 0.00 & 0.46 & 0.37 & 0.06 & -0.17 & 0.17 & 0.17 & -0.24 & -0.15 & -0.06 & 0.20 & 0.36 & -0.07 & & 0.23 & 0.02 & -0.10 \\
\hline CityCost & 0.34 & -0.16 & -0.23 & 0.02 & 0.03 & -0.02 & 0.21 & 0.26 & 0.04 & -0.10 & 0.08 & 0.10 & -0.15 & -0.10 & 0.00 & 0.08 & 0.16 & -0.05 & 0.18 & & 0.00 & -0.03 \\
\hline TenureDum & 0.03 & -0.01 & -0.02 & 0.64 & 0.71 & -0.05 & 0.04 & 0.02 & 0.00 & -0.01 & -0.02 & 0.04 & -0.02 & 0.01 & 0.02 & 0.00 & 0.00 & 0.00 & 0.02 & 0.00 & & -0.09 \\
\hline Initial & -0.14 & 0.08 & 0.09 & -0.11 & -0.13 & -0.02 & -0.13 & -0.08 & 0.00 & 0.00 & -0.04 & -0.06 & 0.07 & 0.05 & 0.02 & -0.05 & -0.05 & 0.05 & -0.09 & -0.03 & -0.09 & \\
\hline
\end{tabular}

Pearson and Spearman correlations are reported above and below the diagonal, respectively. Variables are as defined in Table 1. Bold coefficients are significant at $p<0.05$. 
Table 6: Regression of audit fees on interim and annual partner rotation

\begin{tabular}{|c|c|c|c|c|c|c|c|c|}
\hline & $\begin{array}{l}\text { Exp. } \\
\text { Sign }\end{array}$ & $\begin{array}{c}\text { Full } \\
\text { sample }\end{array}$ & $\begin{array}{c}\text { (2) } \\
\text { Full } \\
\text { sample }\end{array}$ & $\begin{array}{l}\text { Rotation } \\
\text { Sample }\end{array}$ & $\begin{array}{c}\text { High } \\
\text { Bargainin } \\
\text { g Power } \\
\text { sample } \\
\end{array}$ & $\begin{array}{c}\text { High } \\
\text { Bargainin } \\
\text { g Power } \\
\text { sample }\end{array}$ & $\begin{array}{c}\text { (6) } \\
\text { Low } \\
\text { Bargainin } \\
\text { g Power } \\
\text { sample }\end{array}$ & $\begin{array}{c}(7) \\
\text { Low } \\
\text { Bargainin } \\
\text { g Power } \\
\text { sample }\end{array}$ \\
\hline Rotation & $?$ & $\begin{array}{l}0.034 \\
(1.37)\end{array}$ & & & $\begin{array}{l}-0.049 \\
(-1.44)\end{array}$ & & $\begin{array}{c}0.088 * * * \\
(2.63)\end{array}$ & \\
\hline $\begin{array}{l}\text { RotationR } \\
\text { eview }\end{array}$ & + & & $\begin{array}{c}0.069 * * \\
(2.41)\end{array}$ & $\begin{array}{c}0.113 * * \\
(2.27)\end{array}$ & & $\begin{array}{l}-0.012 \\
(-0.30)\end{array}$ & & $0.128 * * *$ \\
\hline $\begin{array}{l}\text { RotationA } \\
\text { udit }\end{array}$ & - & & $\begin{array}{l}-0.056 \\
(-1.34)\end{array}$ & & & $\begin{array}{c}-0.135^{* *} \\
(-2.38)\end{array}$ & & $\begin{array}{l}-0.029 \\
(-0.47)\end{array}$ \\
\hline $\operatorname{LnTA}$ & + & $\begin{array}{c}0.391 * * * \\
(20.81)\end{array}$ & $\begin{array}{c}0.391 * * * \\
(20.74)\end{array}$ & $\begin{array}{c}0.427 * * * \\
(17.96)\end{array}$ & $\begin{array}{c}0.415 * * * \\
(19.41)\end{array}$ & $\begin{array}{c}0.415 * * * \\
(19.30)\end{array}$ & $\begin{array}{c}0.308 * * * \\
(15.12)\end{array}$ & $\begin{array}{c}0.307 * * * \\
(15.10)\end{array}$ \\
\hline SqrtSub & + & $\begin{array}{c}0.082 * * * \\
(8.32)\end{array}$ & $\begin{array}{c}0.082 * * * \\
(8.33)\end{array}$ & $\begin{array}{c}0.071 * * * \\
(5.48)\end{array}$ & $\begin{array}{c}0.057 * * * \\
(4.61)\end{array}$ & $\begin{array}{c}0.057 * * * \\
(4.61)\end{array}$ & $\begin{array}{c}0.083 * * * \\
(7.77)\end{array}$ & $\begin{array}{c}0.083 * * * \\
(7.78)\end{array}$ \\
\hline Foreign & + & $\begin{array}{c}0.590 * * * \\
(10.41)\end{array}$ & $\begin{array}{c}0.591 * * * \\
(10.42)\end{array}$ & $\begin{array}{c}0.764 * * * \\
(10.05)\end{array}$ & $\begin{array}{c}0.646 * * * \\
(9.55)\end{array}$ & $\begin{array}{c}0.645^{* * * *} \\
(9.53)\end{array}$ & $\begin{array}{c}0.433 * * * \\
(6.97)\end{array}$ & $\begin{array}{c}0.437 * * * \\
(7.02)\end{array}$ \\
\hline Current & - & $\begin{array}{c}-0.008 * * * \\
(-5.81)\end{array}$ & $\begin{array}{c}-0.008 * * * \\
(-5.84)\end{array}$ & $\begin{array}{c}-0.009 * * * \\
(-3.81)\end{array}$ & $\begin{array}{c}-0.006 * * * \\
(-3.91)\end{array}$ & $\begin{array}{c}-0.006 * * * \\
(-3.93)\end{array}$ & $\begin{array}{c}-0.009 * * * \\
(-5.23)\end{array}$ & $\begin{array}{c}-0.009 * * * \\
(-5.26)\end{array}$ \\
\hline$D E$ & + & $\begin{array}{l}0.030 \\
(1.18)\end{array}$ & $\begin{array}{l}0.029 \\
(1.16)\end{array}$ & $\begin{array}{l}0.021 \\
(0.70)\end{array}$ & $\begin{array}{l}0.001 \\
(0.02)\end{array}$ & $\begin{array}{l}-0.000 \\
(-0.00)\end{array}$ & $\begin{array}{l}0.042 \\
(1.31)\end{array}$ & $\begin{array}{l}0.042 \\
(1.30)\end{array}$ \\
\hline$R O A$ & - & $\begin{array}{c}-0.340 * * * \\
(-6.81)\end{array}$ & $\begin{array}{c}-0.343 * * * \\
(-6.89)\end{array}$ & $\begin{array}{c}-0.328 * * * \\
(-4.49)\end{array}$ & $\begin{array}{c}-0.458 * * * \\
(-7.86)\end{array}$ & $\begin{array}{c}-0.464 * * * \\
(-7.91)\end{array}$ & $\begin{array}{c}-0.232 * * * \\
(-3.46)\end{array}$ & $\begin{array}{c}-0.231 * * * \\
(-3.46)\end{array}$ \\
\hline Loss & - & $\begin{array}{c}-0.149 * * * \\
(-4.41)\end{array}$ & $\begin{array}{c}-0.151 * * * \\
(-4.46)\end{array}$ & $\begin{array}{l}-0.050 \\
(-1.06)\end{array}$ & $\begin{array}{c}-0.193 * * * \\
(-4.32)\end{array}$ & $\begin{array}{c}-0.195 * * * \\
(-4.36)\end{array}$ & $\begin{array}{c}-0.101 * * \\
(-2.57)\end{array}$ & $\begin{array}{c}-0.103 * * * \\
(-2.61)\end{array}$ \\
\hline$Y E$ & + & $\begin{array}{l}-0.049 \\
(-1.05)\end{array}$ & $\begin{array}{l}-0.048 \\
(-1.04)\end{array}$ & $\begin{array}{l}-0.030 \\
(-0.55)\end{array}$ & $\begin{array}{l}-0.028 \\
(-0.46)\end{array}$ & $\begin{array}{l}-0.027 \\
(-0.45)\end{array}$ & $\begin{array}{c}-0.089^{*} \\
(-1.65)\end{array}$ & $\begin{array}{c}-0.089 * \\
(-1.65)\end{array}$ \\
\hline CEOChair & $?$ & $\begin{array}{c}-0.089 * * \\
(-2.06)\end{array}$ & $\begin{array}{c}-0.087 * * \\
(-2.02)\end{array}$ & $\begin{array}{c}-0.124 * \\
(-1.82)\end{array}$ & $\begin{array}{c}-0.167 * * * \\
(-3.04)\end{array}$ & $\begin{array}{c}-0.164 * * * \\
(-2.97)\end{array}$ & $\begin{array}{l}-0.003 \\
(-0.04)\end{array}$ & $\begin{array}{l}-0.003 \\
(-0.05)\end{array}$ \\
\hline IndepDir & $?$ & $\begin{array}{l}0.023 \\
(0.22)\end{array}$ & $\begin{array}{l}0.022 \\
(0.21)\end{array}$ & $\begin{array}{l}-0.145 \\
(-0.84)\end{array}$ & $\begin{array}{l}-0.052 \\
(-0.37)\end{array}$ & $\begin{array}{l}-0.055 \\
(-0.38)\end{array}$ & $\begin{array}{l}0.107 \\
(0.84)\end{array}$ & $\begin{array}{l}0.108 \\
(0.85)\end{array}$ \\
\hline Big4 & + & $\begin{array}{c}0.330 * * * \\
(9.31)\end{array}$ & $\begin{array}{c}0.330 * * * \\
(9.33)\end{array}$ & $\begin{array}{c}0.339 * * * \\
(7.26)\end{array}$ & $\begin{array}{c}0.572 * * * \\
(9.43)\end{array}$ & $\begin{array}{c}0.574 * * * \\
(9.43)\end{array}$ & $\begin{array}{c}0.518 * * * \\
(9.12)\end{array}$ & $\begin{array}{c}0.520 * * * \\
(9.16)\end{array}$ \\
\hline Modified & + & $\begin{array}{c}0.127 * * * \\
(3.16)\end{array}$ & $\begin{array}{c}0.127 * * * \\
(3.15)\end{array}$ & $\begin{array}{l}0.024 \\
(0.34)\end{array}$ & $\begin{array}{c}0.153 * * * \\
(2.80)\end{array}$ & $\begin{array}{c}0.152 * * * \\
(2.77)\end{array}$ & $\begin{array}{l}0.051 \\
(1.05)\end{array}$ & $\begin{array}{c}0.051 \\
(1.05)\end{array}$ \\
\hline LnNAS & + & $\begin{array}{c}0.021 * * * \\
(6.29)\end{array}$ & $\begin{array}{c}0.021 * * * \\
(6.32)\end{array}$ & $\begin{array}{c}0.021 * * * \\
(3.87)\end{array}$ & $\begin{array}{c}0.019 * * * \\
(4.06)\end{array}$ & $\begin{array}{c}0.019 * * * \\
(4.07)\end{array}$ & $\begin{array}{c}0.022 * * * \\
(5.14)\end{array}$ & $\begin{array}{c}0.022 * * * \\
(5.14)\end{array}$ \\
\hline CityCost & + & $\begin{array}{c}0.179 * * * \\
(4.98)\end{array}$ & $\begin{array}{c}0.178 * * * \\
(4.95)\end{array}$ & $\begin{array}{c}0.164 * * * \\
(3.80)\end{array}$ & $\begin{array}{c}0.324 * * * \\
(6.43)\end{array}$ & $\begin{array}{c}0.323 * * * \\
(6.41)\end{array}$ & $\begin{array}{c}0.158 * * * \\
(3.13)\end{array}$ & $\begin{array}{c}0.156^{* * *} \\
(3.12)\end{array}$ \\
\hline TenureDum & $?$ & $\begin{array}{l}-0.030 \\
(-0.83)\end{array}$ & $\begin{array}{l}-0.063 \\
(-1.64)\end{array}$ & $\begin{array}{l}-0.062 \\
(-1.58)\end{array}$ & $\begin{array}{c}0.096^{*} \\
(1.94)\end{array}$ & $\begin{array}{l}0.060 \\
(1.16)\end{array}$ & $\begin{array}{c}-0.129 * * * \\
(-2.59)\end{array}$ & $\begin{array}{c}-0.167 * * * \\
(-3.15)\end{array}$ \\
\hline Initial & - & $\begin{array}{c}-0.140 * * * \\
(-4.06)\end{array}$ & $\begin{array}{c}-0.140 * * * \\
(-4.07)\end{array}$ & $\begin{array}{c}0.574 * * * \\
(5.70)\end{array}$ & $\begin{array}{l}-0.046 \\
(-0.96)\end{array}$ & $\begin{array}{l}-0.046 \\
(-0.96)\end{array}$ & $\begin{array}{c}-0.197 * * * \\
(-4.29)\end{array}$ & $\begin{array}{c}-0.198 * * * \\
(-4.30)\end{array}$ \\
\hline Constant & & $\begin{array}{c}3.696 * * * \\
(10.87)\end{array}$ & $\begin{array}{c}3.707 * * * \\
(10.88)\end{array}$ & $\begin{array}{c}3.054 * * * \\
(7.05)\end{array}$ & $\begin{array}{c}3.327 * * * \\
(8.36)\end{array}$ & $\begin{array}{c}3.336 * * * \\
(8.33)\end{array}$ & $\begin{array}{c}4.956 * * * \\
(13.69)\end{array}$ & $\begin{array}{c}4.972 * * * \\
(13.76)\end{array}$ \\
\hline $\begin{array}{l}\text { Industry } \\
\text { FE }\end{array}$ & & Yes & Yes & Yes & Yes & Yes & Yes & Yes \\
\hline $\begin{array}{l}\text { Year FE } \\
\text { Observatio }\end{array}$ & & Yes & Yes & Yes & Yes & Yes & Yes & Yes \\
\hline $\begin{array}{l}\text { ns } \\
\text { Adjusted }\end{array}$ & & 3,480 & 3,480 & 769 & 1,740 & 1,740 & 1,740 & 1,740 \\
\hline $\mathrm{R}^{2}$ & & 0.839 & 0.839 & 0.843 & 0.895 & 0.895 & 0.769 & 0.769 \\
\hline
\end{tabular}

The dependent variable is the natural logarithm of audit fees. Variables are as defined in Table 1. Two-tailed test of significance: $* * *=$ less than $0.01, * *=$ less than 0.05 and $*=$ less than 0.10 . 
Table 7: Regression of audit fees on voluntary interim and annual partner rotation

\begin{tabular}{|c|c|c|c|c|c|c|c|c|}
\hline & Exp. Sign & $\begin{array}{c}\text { (1) } \\
\text { Full sample }\end{array}$ & $\begin{array}{c}(2) \\
\text { High } \\
\text { Bargaining } \\
\text { Power sample }\end{array}$ & $\begin{array}{c}(3) \\
\text { Low } \\
\text { Bargaining } \\
\text { Power sample }\end{array}$ & $\begin{array}{c}(4) \\
\text { Big } 4 \\
\text { sample }\end{array}$ & $\begin{array}{c}\text { (5) } \\
\text { non-Big } 4 \\
\text { sample }\end{array}$ & $\begin{array}{c}\text { (6) } \\
\text { Large } \\
\text { Clients } \\
\text { sample }\end{array}$ & $\begin{array}{c}(7) \\
\text { Small } \\
\text { Clients } \\
\text { sample }\end{array}$ \\
\hline RotationReview $*$ VPR & + & $0.065 * *$ & -0.014 & $0.126 * * *$ & & & & \\
\hline & & $(2.25)$ & $(-0.34)$ & $(3.17)$ & & & & \\
\hline RotationAudit*VPR & - & $\begin{array}{l}-0.047 \\
(-1.09)\end{array}$ & $\begin{array}{c}-0.132 * * \\
(-2.29)\end{array}$ & $\begin{array}{l}-0.023 \\
(-0.36)\end{array}$ & & & & \\
\hline RotationReview & + & & & & $\begin{array}{c}0.086 * * \\
(2.51)\end{array}$ & $\begin{array}{l}0.030 \\
(0.62)\end{array}$ & $\begin{array}{l}0.026 \\
(0.71)\end{array}$ & $\begin{array}{c}0.128 * * * \\
(2.27)\end{array}$ \\
\hline RotationAudit & - & & & & $\begin{array}{l}-0.048 \\
(-0.89)\end{array}$ & $\begin{array}{c}-0.185^{* * * *} \\
(-3.10)\end{array}$ & $\begin{array}{c}-0.109 * \\
(-1.84)\end{array}$ & $\begin{array}{l}-0.013 \\
(-0.24)\end{array}$ \\
\hline LnTA & + & $\begin{array}{c}0.391 * * * \\
(20.75)\end{array}$ & $\begin{array}{c}0.415 * * * \\
(19.30)\end{array}$ & $\begin{array}{c}0.307 * * * \\
(15.10)\end{array}$ & $\begin{array}{c}0.416 * * * \\
(19.41)\end{array}$ & $\begin{array}{c}0.306 * * * \\
(12.45)\end{array}$ & $\begin{array}{c}0.477 * * * \\
(16.75)\end{array}$ & $\begin{array}{c}0.249 * * * \\
(11.19)\end{array}$ \\
\hline SqrtSub & + & $\begin{array}{c}0.082 * * * \\
(8.32)\end{array}$ & $\begin{array}{c}0.057 * * * \\
(4.61)\end{array}$ & $\begin{array}{c}0.083 * * * \\
(7.78)\end{array}$ & $\begin{array}{c}0.074 * * * \\
(6.81)\end{array}$ & $\begin{array}{c}0.110 * * * \\
(5.85)\end{array}$ & $\begin{array}{c}0.066 * * * \\
(5.95)\end{array}$ & $\begin{array}{c}0.083 * * * \\
(4.72)\end{array}$ \\
\hline Foreign & + & $\begin{array}{c}0.591 * * * \\
(10.41)\end{array}$ & $\begin{array}{c}0.645^{* * * *} \\
(9.53)\end{array}$ & $\begin{array}{c}0.436 * * * \\
(6.99)\end{array}$ & $\begin{array}{c}0.697 * * * \\
(9.18)\end{array}$ & $\begin{array}{c}0.364 * * * \\
(5.14)\end{array}$ & $\begin{array}{c}0.832 * * * \\
(10.75)\end{array}$ & $\begin{array}{c}0.466 * * * \\
(6.77)\end{array}$ \\
\hline Current & - & $\begin{array}{c}-0.008 * * * \\
(-5.83)\end{array}$ & $\begin{array}{c}-0.006^{* * * *} \\
(-3.93)\end{array}$ & $\begin{array}{c}-0.009 * * * * \\
(-5.25)\end{array}$ & $\begin{array}{c}-0.009 * * * * \\
(-4.98)\end{array}$ & $\begin{array}{c}-0.006^{* * * *} \\
(-3.45)\end{array}$ & $\begin{array}{c}-0.008 * * * \\
(-4.59)\end{array}$ & $\begin{array}{c}-0.007 * * * \\
(-5.58)\end{array}$ \\
\hline$D E$ & + & $\begin{array}{l}0.029 \\
(1.16)\end{array}$ & $\begin{array}{l}0.000 \\
(0.00)\end{array}$ & $\begin{array}{l}0.042 \\
(1.31)\end{array}$ & $\begin{array}{l}0.026 \\
(0.95)\end{array}$ & $\begin{array}{l}0.059 \\
(1.51)\end{array}$ & $\begin{array}{l}-0.009 \\
(-0.25)\end{array}$ & $\begin{array}{c}0.058 * * \\
(2.41)\end{array}$ \\
\hline$R O A$ & - & $\begin{array}{c}-0.342 * * * \\
(-6.83)\end{array}$ & $\begin{array}{c}-0.462 * * * \\
(-7.89)\end{array}$ & $\begin{array}{c}-0.232 * * * * \\
(-3.46)\end{array}$ & $\begin{array}{c}-0.363 * * * \\
(-5.06)\end{array}$ & $\begin{array}{c}-0.284 * * * \\
(-4.71)\end{array}$ & $\begin{array}{c}-0.541 * * * \\
(-3.37)\end{array}$ & $\begin{array}{c}-0.181 * * * \\
(-3.36)\end{array}$ \\
\hline Loss & - & $\begin{array}{c}-0.151 * * * \\
(-4.46)\end{array}$ & $\begin{array}{c}-0.195 * * * \\
(-4.35)\end{array}$ & $\begin{array}{c}-0.103 * * * * \\
(-2.63)\end{array}$ & $\begin{array}{c}-0.114 * * * * \\
(-2.89)\end{array}$ & $\begin{array}{c}-0.232 * * * \\
(-3.83)\end{array}$ & $\begin{array}{c}-0.118 * * \\
(-2.46)\end{array}$ & $\begin{array}{c}-0.175 * * * \\
(-4.14)\end{array}$ \\
\hline$Y E$ & + & $\begin{array}{l}-0.048 \\
(-1.04)\end{array}$ & $\begin{array}{l}-0.027 \\
(-0.45)\end{array}$ & $\begin{array}{c}-0.089 * \\
(-1.65)\end{array}$ & $\begin{array}{l}-0.026 \\
(-0.53)\end{array}$ & $\begin{array}{c}-0.208^{*} \\
(-1.86)\end{array}$ & $\begin{array}{l}-0.050 \\
(-0.96)\end{array}$ & $\begin{array}{l}-0.021 \\
(-0.32)\end{array}$ \\
\hline CEOChair & $?$ & $\begin{array}{c}-0.088 * * \\
(-2.03)\end{array}$ & $\begin{array}{c}-0.165^{* * *} \\
(-2.99)\end{array}$ & $\begin{array}{l}-0.003 \\
(-0.05)\end{array}$ & $\begin{array}{l}-0.082 \\
(-1.47)\end{array}$ & $\begin{array}{l}-0.049 \\
(-0.76)\end{array}$ & $\begin{array}{l}-0.096 \\
(-1.58)\end{array}$ & $\begin{array}{l}-0.042 \\
(-0.80)\end{array}$ \\
\hline IndepDir & $?$ & $\begin{array}{l}0.022 \\
(0.21)\end{array}$ & $\begin{array}{l}-0.056 \\
(-0.39)\end{array}$ & $\begin{array}{c}0.108 \\
(0.85)\end{array}$ & $\begin{array}{l}0.017 \\
(0.12)\end{array}$ & $\begin{array}{l}-0.075 \\
(-0.56)\end{array}$ & $\begin{array}{l}0.004 \\
(0.03)\end{array}$ & $\begin{array}{l}0.050 \\
(0.41)\end{array}$ \\
\hline Big4 & + & $\begin{array}{c}0.330 * * * \\
(9.33)\end{array}$ & $\begin{array}{c}0.574 * * * \\
(9.43)\end{array}$ & $\begin{array}{c}0.521 * * * \\
(9.17)\end{array}$ & & & $\begin{array}{c}0.277 * * * \\
(5.58)\end{array}$ & $\begin{array}{c}0.400 * * * \\
(8.79)\end{array}$ \\
\hline Modified & + & $0.127 * * *$ & $0.153 * * *$ & 0.051 & $0.103 * *$ & $0.099 *$ & 0.036 & $0.155 * * *$ \\
\hline
\end{tabular}




\begin{tabular}{|c|c|c|c|c|c|c|c|c|}
\hline & & (3.16) & $(2.78)$ & (1.06) & (2.11) & (1.67) & $(0.63)$ & $(3.23)$ \\
\hline LnNAS & + & $\begin{array}{c}0.021 * * * \\
(6.31)\end{array}$ & $\begin{array}{c}0.019 * * * \\
(4.08)\end{array}$ & $\begin{array}{c}0.022 * * * \\
(5.14)\end{array}$ & $\begin{array}{c}0.023 * * * \\
(5.37)\end{array}$ & $\begin{array}{c}0.017 * * * * \\
(3.21)\end{array}$ & $\begin{array}{c}0.027 * * * \\
(5.09)\end{array}$ & $\begin{array}{c}0.016 * * * \\
(3.92)\end{array}$ \\
\hline CityCost & + & $\begin{array}{c}0.178 * * * \\
(4.95)\end{array}$ & $\begin{array}{c}0.324 * * * \\
(6.41)\end{array}$ & $\begin{array}{c}0.157 * * * \\
(3.12)\end{array}$ & $\begin{array}{c}0.154 * * * \\
(3.69)\end{array}$ & $\begin{array}{c}0.212 * * * * \\
(3.74)\end{array}$ & $\begin{array}{c}0.124 * * * \\
(2.72)\end{array}$ & $\begin{array}{c}0.177 * * * \\
(4.03)\end{array}$ \\
\hline TenureDum & $?$ & $\begin{array}{l}0.004 \\
(0.15)\end{array}$ & $\begin{array}{l}0.047 \\
(1.38)\end{array}$ & $\begin{array}{l}-0.041 \\
(-1.17)\end{array}$ & $\begin{array}{c}-0.105 * * \\
(-2.19)\end{array}$ & $\begin{array}{l}0.045 \\
(0.76)\end{array}$ & $\begin{array}{l}0.016 \\
(0.29)\end{array}$ & $\begin{array}{c}-0.161 * * * \\
(-3.25)\end{array}$ \\
\hline Initial & - & $\begin{array}{c}-0.140 * * * \\
(-4.07)\end{array}$ & $\begin{array}{l}-0.046 \\
(-0.96)\end{array}$ & $\begin{array}{c}-0.197 * * * \\
(-4.30)\end{array}$ & $\begin{array}{c}-0.204 * * * \\
(-4.63)\end{array}$ & $\begin{array}{l}-0.028 \\
(-0.54)\end{array}$ & $\begin{array}{c}-0.187 * * * \\
(-3.01)\end{array}$ & $\begin{array}{c}-0.117 * * * \\
(-2.97)\end{array}$ \\
\hline Constant & & $\begin{array}{c}3.705^{* * *} \\
(10.88)\end{array}$ & $\begin{array}{c}3.337 * * * \\
(8.33)\end{array}$ & $\begin{array}{c}4.970 * * * \\
(13.75)\end{array}$ & $\begin{array}{c}3.581 * * * \\
(9.14)\end{array}$ & $\begin{array}{c}5.335^{* * * *} \\
(11.93)\end{array}$ & $\begin{array}{c}2.075^{* * *} * \\
(3.78)\end{array}$ & $\begin{array}{c}6.147 * * * \\
(16.38)\end{array}$ \\
\hline
\end{tabular}

Industry FE

Year FE

Yes Yes

Observations

Yes Yes

Adjusted $\mathrm{R}^{2}$

$\begin{array}{ll}3,480 & 1,740 \\ 0.839 & 0.895\end{array}$

Yes

Yes

Yes Yes

Yes Yes

$1,740 \quad 1,008$

$\begin{array}{lllll}0.769 & 0.806 & 0.750 & 0.783 & 0.660\end{array}$

The dependent variable is the natural logarithm of audit fees. Variables are as defined in Table 1. Two-tailed test of significance: $* * *=$ less than $0.01, * *=$ less than 0.05 and $*=$ less than 0.10 
Table 8: Regression of audit reporting lag on interim and annual partner rotation

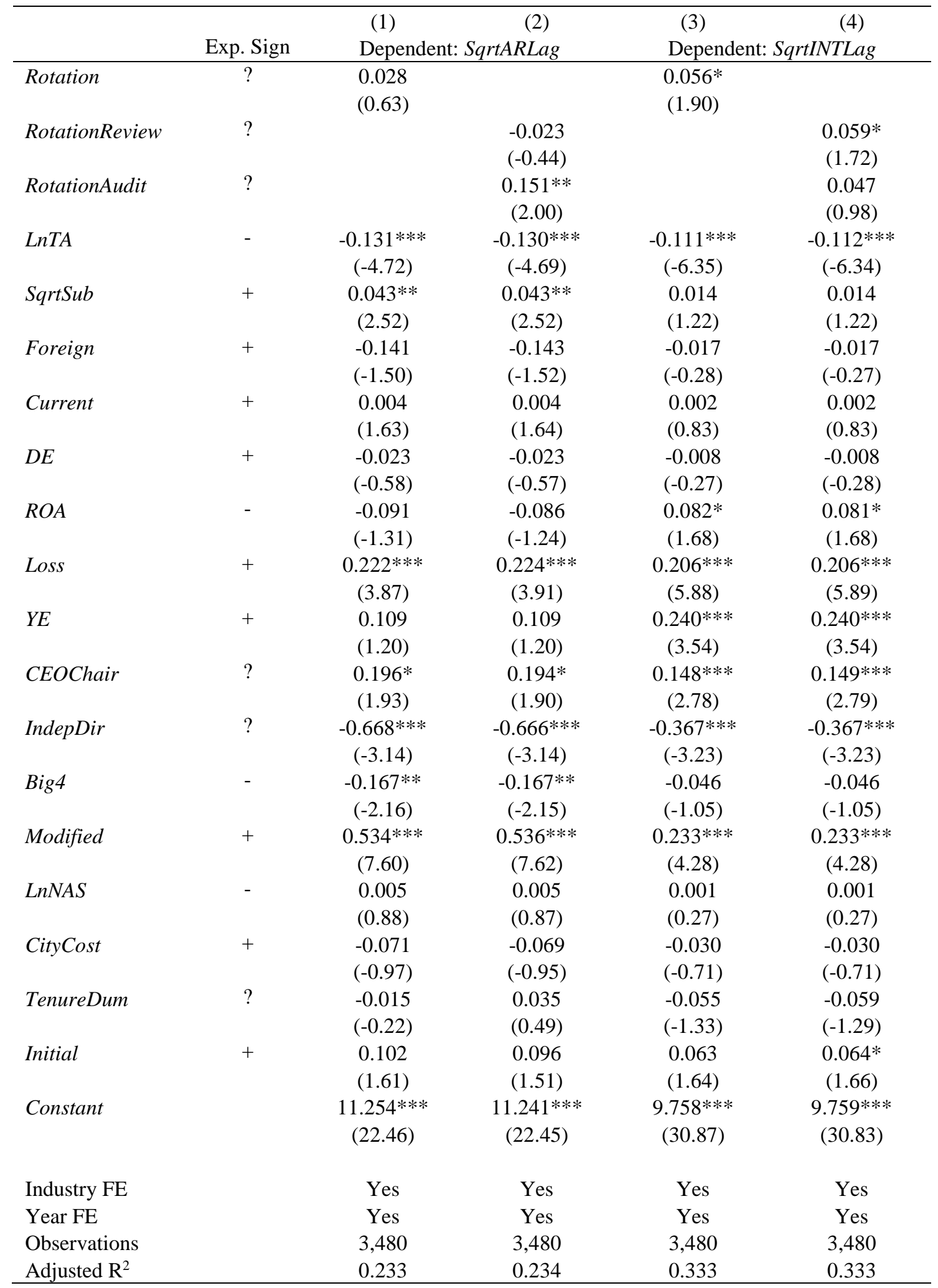

The dependent variables are: SqrtARLag, the difference in days between the financial year-end date and the reported signing of the annual report audit opinion; SqrtINTLag, calculated as the difference in days between the interim half year-end date and the reported signing date of the interim financial statements review conclusion and other variables are as defined in Table 1 . Two-tailed test of significance: $* * *=$ less than 0.01 , ** $=$ less than 0.05 and $*=$ less than 0.10 . 